Article

\title{
Pathologic and Risk Analysis of the Lojuela Castle (Granada-Spain): Methodology and Preventive Conservation for Medieval Earthen Fortifications
}

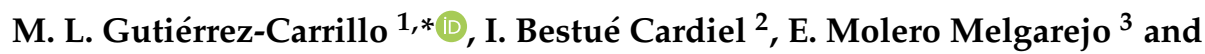 \\ M. Marcos Cobaleda ${ }^{4}$ (D) \\ 1 Departamento de Construcciones Arquitectónicas, Universidad de Granada, 18071 Granada, Spain \\ 2 Departamento de Expresión Gráfica Arquitectónica y en la Ingeniería, Universidad de Granada, \\ 18071 Granada, Spain; ibestue@gmail.com \\ 3 Departamento de Urbanística y Ordenación del Territorio, Universidad de Granada, 18071 Granada, Spain; \\ emiliomolero@ugr.es \\ 4 Departamento de Historia del Arte, Universidad de Málaga, 29071 Málaga, Spain; mmcobaleda@uma.es \\ * Correspondence: mlgutier@ugr.es; Tel.: +34-958241000 (ext. 20034)
}

Received: 2 July 2020; Accepted: 12 September 2020; Published: 17 September 2020

\begin{abstract}
This study presents a methodology generated for the preventive conservation of defensive earthen architecture, applied to the case of the Lojuela Castle (Lecrin Valley, Granada, Spain). In the application of the designed protocol, a multidisciplinary analysis of its patrimonial characteristics and multidimensional evaluation was developed, applying the technique of qualitative consultation to a group of experts-the Delphi method. This methodology allowed us to relate the hazard factors and the vulnerability of the asset for each group of risks that affect it. The support of the method in with geographic information systems (GIS) has favored the production of predictive cartography and risk analysis-including the territorial dimensions and spatial interactions of the asset with the physical environment. This has facilitated the obtention of micro-zoning maps of each of the risks examined. The risk mapping in micro-zoning and the knowledge of the structure's vulnerability represents an important contribution to the future conservation and management of this heritage. They favor strategies that minimize the incidence of risks and allow the prioritization of the conservation actions with a minimum economic investment, creating an efficient maintenance program. This will facilitate the protection, conservation and valorization decisions by the administration and the competent bodies involved in the protection of these sites.
\end{abstract}

Keywords: risk factors; preventive conservation; medieval earthen defensive architecture; pathologic analysis

\section{Introduction}

During recent years, the model of action on cultural heritage has tended to protect, preserve and safeguard this heritage, promoting its enrichment and use as a social asset and a factor of sustainable development. In this way, the model contributes to reducing the challenge represented by the transformation processes that suffer and which compromise its meaning, values, integrity and diversity [1].

A large part of the cultural legacy suffers a significant process of degradation due to the constant action of different factors of alteration, both natural and anthropic [2]. It is worth highlighting the high exposure of these to the action of environmental factors [3], in addition to those related to geomorphological actions [4-6] or the action of floods and fires [7]. The factors of anthropic origin must also be added: acts of vandalism, inappropriate restorations or the absence of urban planning that is in 
line with the protection of heritage. Among the causes that increase the effects of the previous ones, it is necessary to emphasize the lack of adequate maintenance of these structures [8,9], which is responsible for material damage of the asset as well as the loss of heritage values, even compromising the safety of people. The damage caused not only affects each specific asset, but also encourages the degradation of the environment. Considering this reality, the design of preventive conservation and maintenance strategies is essential in order to guarantee more sustainable protection and conservation [10-12].

Attention to the threats and the situation of degradation of heritage as a tool to prevent major deterioration and extend the life of buildings $[7,13]$ has had a decisive influence on updating and rethinking the protocols for analysis and intervention in cultural heritage. This practice has resulted in a significant reduction in the economic investments necessary for its restoration and repair of damage. The elaboration in 1987 of the Charter of the Risk of Cultural Heritage in Italy marks a real turning point. This Charter was based on the determination of systems and procedures that made the schedule of maintenance and conservation interventions possible and had a direct application in theoretical and methodological developments and operational plans for programmed conservation [14]. From the perspective of a territorial vision, the main factors that cause the deterioration of cultural assets were analyzed and maps and risk charts were generated as an essential planning tool in the practice of preventive management of cultural assets. Nevertheless, this planning tool worked from the macrozoning perspective, not from the detail of the microzoning, which represented a key factor in the correct diagnosis. It should be noted that the Charter did not address the notion of vulnerability [15].

From that moment, the use of the spatial analysis capabilities of geographical information systems (GIS) as a tool for evaluation, diagnosis and control in the field of conservation [16] and from the perspective of territorial planning and risks has been increasing. Some studies have highlighted the absence of hazard maps in urban plans, calling for their inclusion [12]. Other works provide information on the probability of hazards in urban areas to prioritize preventive conservation actions and restorations [17] or others identify areas susceptible to geomorphological hazards that threaten cultural and natural heritage [6]. Moreover, the studies that focus on the development of analytical methodologies for risk assessment and treatment control are outstanding. They combine GIS and digital image analysis (DIA), used in assessing the effectiveness of biocides [18], the study of black crusts on buildings [19] or the effect of traffic on the facades of stone buildings [20].

In recent years there has been an increase in studies on the conservation of cultural heritage. The origins of preventive conservation and its historical evolution have been highlighted [21,22]. However, the advance of this model of action from other disciplines has played a fundamental role in the development of applied science with a specific technology [23-26]. This fact has made possible a greater and better knowledge of the cultural asset and its materiality, as the origin of intrinsic risks [27] or of the evaluation of threats [28]. Satellite remote sensing systems have been integrated into the study for risk assessment [29], even in combination with dispersive X-ray spectroscopy (SEM-EDX) to determine small-scale pathologies in walls [30].

Other research has focused on the development of methodologies based on the use of artificial intelligence, creating models for predicting the useful life of the building based on fuzzy logic, which determines and evaluates the factors that affect vulnerability and risks that affect the asset [15,31]. There are other models based on prediction methodologies supported by statistical probability data [32]. The works that employ multicriteria techniques such as analytical hierarchy process (AHP) must be added. The application of the AHP has allowed the assessment of the appropriateness of a change of use, different from the original, in industrial buildings, without reducing their heritage values. This change contributes to their sustainable conservation [33] and has allowed a new approach for developing evaluation models of the potential sustainable energy rehabilitation of historical buildings [34].

It should be pointed out that the identification, evaluation and control of certain variables from multidisciplinary approaches for the design of preventive conservation and maintenance strategies were mainly developed in the context of museums [26,35,36]. However, the Vantaa Resolution [37] and the Krakow Charter [11] have extended the scope of preventive conservation and extend the 
intervention model to any cultural asset, including buildings. Since then, preventive conservation has become the main strategy of European policies in the field of heritage conservation [38,39].

Actions within the framework of preventive conservation [40] imply the definition of an effective and systematic methodology to identify [38], evaluate and control the threats that affect all cultural assets [41-46]. The aim of these actions is to minimize these threats [47-50], thanks to the evaluation of their degree of impact on the effects of deterioration and the development of appropriate measures to avoid or, at least, slow down their negative effects [39,51].

The strategy established should focus on the multidisciplinary analysis of the cultural asset, its state of conservation and the use and management thereof; the examination of the risks of deterioration, assessment and definition of priorities for action; the establishment of monitoring and control methods, as well as the definition of technical means and working procedures, together with maintenance planning and the design of preventive interventions [52]. At this point, the building information modeling (BIM) methodology has provided substantial benefits in the conservation of buildings by favoring the schedule of maintenance, improving expenditure control and providing the obtaining of ratios and indicators [53].

In this way, there is a direct benefit that avoids their deterioration and loss, in addition, to carrying out more invasive and costly interventions $[39,54,55]$. However, in this context, it should be taken into account that, for its application to architectural heritage, certain particularities must be considered: the evaluation of the economic impact, the participation of society and the concern and interest of the administration in its implementation [56-59].

\section{Background. Earthen Defensive Architecture: Protection, Conservation and Risks}

Defensive heritage, as part of the aforementioned cultural legacy, is not immune to the circumstances described above. In fact, the fatal consequences intensify if compared to other types of heritage [60], and it is currently in an unequal state of conservation and at serious risk of losing its most essential values.

However, international interest in the protection of heritage sites has been present since the 19th century. Over time, it has evolved and acquired greater intensity with profuse promulgation of documents and guidelines that have defined the model of intervention to be carried out on the basis of heritage values and the diagnosis of damage to each asset. This issue has taken on greater force since the second half of the 20th century, under the protection of consultative and advisory bodies and institutions (UNESCO, ICOMOS, ICCROM, Council of Europe) [8].

A turning point came in 1931 with the promulgation of the Athens Charter. This document set the new guidelines that were to govern the restoration of monuments in Europe. This was more focused on conservation than on restoration, including the safeguarding of periodic maintenance work [61]. Taking it as a reference, the Italian Charter of Restoration of 1932 would define the criteria for action, specifying that conservation should affect the traces of all periods on the building. This went deeper into anastylosis as a strategy for the conservation of the built archaeological heritage [62]. The Venice Charter of 1964 would strengthen the consolidation as the main model of intervention. This refers to the maintenance of the archaeological remains-ruins-as a strategy to guarantee the conservation and permanent protection of the architectural archaeological elements. It recognized the primacy of the use of traditional techniques, admitting modern ones when they were inadequate for the exercise of consolidation [63].

Whereas the Convention on the Protection of the World Cultural and Natural Heritage of 1972 defined archaeological remains by recognizing their spatial and architectural values [64], the Italian Charter of Restoration of 1972 emphasizes the particular model of intervention on them, considering their differences in relation to historical architectural monuments. It listed the general criteria for action, the scope of application and the models of intervention, including limitations on the use of insufficiently tested materials. This Convention values maintenance, since it avoids the aggravation of damage, and it recommends the performance of continuous surveillance of the complexes and the adoption of 
preventive measures for both the structures and the surroundings [65]. With the subsequent European Charter of Architectural Heritage of 1975 [66] and the Declaration of Amsterdam of 1975 [67], there is a greater concern for the conservation of the historical architectural heritage, ignoring, among others, the archaeological heritage. In the Charter of Mexico of 1976 in Defense of Cultural Heritage [68] and in the Norms of Quito of 1977 [69], the concept of archaeological monument was taken up again.

The Granada Convention of 1985 defined measures to mitigate the effects of environmental risks-pollution—on assets through a methodology based on scientific research and analysis of the effects. This Convention calls for the application of traditional techniques in their conservation [70]. In 1990, the specific Charter for the Protection and Management of the Archaeological Heritage, justified the creation of inventories in order to achieve global knowledge of these sites; it also addressed the problems of conservation in the face of the lack of economic resources, by obliging their selection based on scientific criteria. Reintegrations are linked to a pedagogical process and establish a direct relationship between this type of intervention and experimental research [71].

In the 21st century, in the face of legal, social, cultural and technological changes, the Krakow Charter of 2000 will be responsible for updating the criteria for conservation and restoration. The Charter recognizes the value of the asset in a state of ruin as an architectural element and highlights the relationship of heritage assets with their environment and landscape. This marks as a model of conservation the minimum intervention-avoiding reconstruction-, the compatibility with the asset of materials and techniques used and the reversibility of the actions. The use of modern technology for the public management of the ensembles is recommended, giving priority to the use of data banks, computer systems and virtual models of dissemination [11].

Despite these efforts and advances by institutions and organizations, the importance of the application of the postulates has depended on their reception and incorporation into national and regional legislation [8]. In Spain and specifically for defensive architecture, there have been protection strategies that have intensified in recent decades. The Decree on the Protection of Spanish Castles of 1949 stands out as the first generic protection standard for defensive architecture. Among its objectives, it states that all castles, regardless of their state of ruin, would be under the protection of the state [72]. Subsequently, the Spanish Constitution of 1978 provided the state, as well as the regional and local administrations, with new powers and responsibilities in the area of protection of historic heritage [73]. The Law 16/1985 of June 25, 1985, on Spanish Historic Heritage, grants the highest level of protection to the castles, that of an "Asset of Cultural Interest" (BIC) [74]. As from the enactment of this law, in those regions with transferred competences regarding the protection of heritage, the regional administration will be the one to process and approve the BIC applications for the other fortified structures not yet protected-walls or towers. Thus, the regional administration will be responsible for their protection [75]. In 1998, the General Directorate of Fine Arts revised the management model for fortified heritage by promoting an inventory of castles and structures of a defensive nature [76]. In 2006, the Charter of Baños de la Encina was promulgated [77] with recommendations agreed upon to address the process of conservation and restoration of these assets. This Charter goes into detail on the need to carry out a multidisciplinary investigation to understand the values of these structures, to define concrete actions and to control the process of intervention by the administrations in charge of their protection, including the definition of the means for preventive conservation and maintenance. Along the same lines, the Institute of Cultural Heritage of Spain drafted the National Plan of Defensive Architecture, a programmatic management document whose objective is to establish a methodology of action for the conservation and restoration of this heritage, to program investments in accordance with conservation needs and to coordinate the participation of the various institutions involved in the management of these structures [60]. With a similar aim, but at a regional level, the development of the Plan for Defensive Architecture in Andalusia [78] should be highlighted. At the local level, the town councils are obliged to include it in the catalog of protection of urban planning. Furthermore, in those cases where they are the owners of these structures, they will be responsible for their conservation and maintenance. 
Despite the legal and patrimonial recognition of protection mentioned above and although the conservation obligations legally incumbent on their owners are mandatory, some circumstances have generated great difficulty in putting into practice effective strategies to reverse this situation. Among them, is the archaeological nature of these sites, their situation in the territory and the fact that ownership falls to individuals or local administrations with scarce economic and material resources.

There is now considerable interest in the medieval defensive earthen architecture in the geographical south east area of the Iberian Peninsula. It can be highlighted a number of lines of research that have focused on the role that these structures have had in historical events [79] and those that have classified the different architectural typologies and their associated functions $[80,81]$. Those that define and provide knowledge of the technical, constructive and material characteristics must be underlined [82-87], allowing the establishment of the relationships between the different techniques and specific properties of each geographical area [88]. Those that have created a chronotypological classification, supported by archaeological methodology, are outstanding $[89,90]$.

In the last decade, research has been directed towards the analytical, chemical and pathologic study of fortified earthen structures to determine intrinsic risk factors in their material [91] as well as the procedures and products applied to their sustainable recovery, based on the use of lime nanoparticles [92]. Of great interest are those based on the restoration experiences themselves, which have carried out a critical evaluation of the conservation criteria, the techniques used and their results. The studies conducted by López Martínez [93-95] and Mileto and Vegas [96-99] are of particular interest; their results are state-of-the-art and have generated a large body of knowledge of international reference [100].

Since its origin, fortified architecture has searched for a strategic position in the territory to accomplish its main functions of defense, surveillance and control. It, therefore, means that its geolocation becomes a key factor in determining the natural and anthropic hazard factors that most affect the state of conservation of these assets [101]. Vulnerability to natural agents is one of the serious problems affecting the buildings of the Andalusian defensive heritage built of rammed earth, where the geomorphological, hydrological and environmental conditions of the territory have a significant negative impact on these structures. Thus, a notable number of defensive structures and other archaeological remains located on promontories are exposed to landslides [102,103], to weather phenomena (wind, rain, hail and/or lightning) or extreme weather conditions, such as coastal weather, with direct action from the sea. The hazards derived from river floods and their effect on the environment [104] and liquefaction processes will be more frequent for those located in lowland areas. The high degree of seismicity in the southeastern provinces of the Iberian Peninsula contributes to the greater repetition of this hazard on the defensive heritage as well. The Alhambra in Granada is a paradigmatic case of seismic vulnerability, and this is reflected in the continuous activity during the last five centuries of the Tajo de San Pedro, where it is located and the associated faults located in the lower part $[105,106]$. The consequence of this location has been the partial damage in its structures by the effects of different earthquakes [107]. The geological studies of the site, the seismotectonic evaluation and the analysis of the seismic vulnerability, together with the measurements of control of movements with different techniques and instrumentation, have been studies of great relevance and have allowed us to know the behavior of some of their structures [108].

Given the absence of preventive conservation protocols for earthen architecture and the particularities and limitations imposed by this heritage, it is necessary to develop an easy, viable and cost-effective methodology to facilitate its management. Therefore, a method is proposed that evaluates in a related way, through the use of qualitative techniques of expert consultation, the risks, both natural and anthropic and the vulnerability of these historical structures, elaborating microzoning risk charts that provide more detail. This strategy allows the anticipation of the behavior of the structures and will favor decision-making by establishing priority and preventive actions on these structures [109]. 


\section{Objectives}

Based on specific approaches to preventive conservation and given the advanced state of deterioration of the defensive structures built with the rammed-earth techniques, it is necessary to design strategies that facilitate the sustainable conservation of this heritage which is difficult to manage. The PREFORTI R+D project, funded by the Spanish Ministry of Economy and Competitiveness, proposes a methodology compatible with this purpose.

Among its main objectives, the following ones can be highlighted: the systematization of a multidisciplinary analysis strategy applicable to each structure, including information on the context of the asset, its use and management; the examination of hazard factors and the evaluation of their impact on the deterioration of the structures of the asset and its environment through the application of multicriteria techniques; the development of preventive action charters in order to establish degrees of priority for action and models of action for specific effects; and the design of monitoring/control methods together with technical procedures, which contribute to the sustainable conservation and maintenance of this heritage.

The support of the geographic information systems methodology will allow the creation of a digital platform that includes predictive and risk analysis mapping. This is innovative since it is committed to the analytical and massive geoprocessing potential of GIS spatial data to address complex geospatial analyses, throughout the evaluation of requirements for the protection and preventive conservation of these cultural assets from a global perspective and at a territorial scale. This methodology will allow for the strategic planning of control actions and the definition of technical means and working procedures necessary to guarantee their safeguarding. Moreover, it will be of maximum use to public administrations and professionals competent in their management and conservation.

This specific methodology developed by the PREFORTI research project [109] has focused on the study of 230 fortifications located in Southeast Spain; among them, the 30 most representative defensive structures were selected on the basis of their size and impact, so as to deepen the study.

This methodology was applied to the case of the Lojuela Castle, located in the Lecrin Valley in the province of Granada (Spain), with implications for its sustainable conservation [110]. To this end, the following specific objectives are proposed:

- To systematize a multidisciplinary analysis model that will be applied to the Lojuela Castle in order to deepen its complete knowledge;

- To detect, analyze and assess the main natural and anthropic hazards to which the Lojuela Castle is exposed, generating specific cartographies for each risk;

- To examine the state of conservation of the castle and elaboration of the pathology maps associated with each type of risk;

- To evaluate the degree of hazard and vulnerability using the Delphi method and estimation of the global risk;

- To design action strategies to preserve and strengthen this cultural asset, both materially and structurally.

\section{Materials and Methods}

The method used was based on the study, analysis and evaluation of the Lojuela Castle under systematized parameters in order to be able to combine and understand the relationship between the hazard factors and the set of damages that the asset presents. Hence the methodology (Figure 1) is divided into five phases:

- Phase of knowledge of the reality of heritage. This consisted of the development of a multidisciplinary analysis that has first understood its georeferencing, from the assignment of UTM coordinates and the establishment of the conditions of the environment. Subsequently, a documentary study was carried out, based on archival and bibliographic information relating to 
historical risks and the restoration work carried out [111]. This was complemented by specific fieldwork involving the inspection and direct collection of data and samples of material for the performance of chemical, mineralogical and petrographic characterization tests in order to determine their material and pathologic nature. X-ray diffraction tests (XRD) were carried out to characterize the mineral phases that make up the construction material samples. Moreover, a petrographic study was carried out to describe the structural, compositional and textural properties that characterize each sample. Scanning electron microscopy (with X-ray microanalysis) was also carried out to find out the composition of the sample in a more specific way and to determine small-scale pathologies. The samples were analyzed using A PANalytical X'Pert3 diffractometer equipped with an automatic slit. Data were interpreted using the XPowder 12 software and database from the International Centre for Diffraction Data, in which JCPDS (the Joint Committee on Powder Diffraction Standards) cards were used to distinguish the different crystalline phases. For the petrographic study, a Carl Zeiss "Jenapol-U" microscope equipped with a digital camera (Nikon D7000) was used. This enabled the identification of the mineral components, their textural and structural ratios, the degree of decay, the presence of neoformation phases and the study of the cement matrix used in the rammed-earth walls and/or mortars (by dyeing with alizarin red) based on observation of thin sections of each material [27]. The scanning electron microscopy study was carried out with a high-resolution Auriga model from Carl Zeiss SMT, which was equipped with a dispersive X-ray spectroscopy (SEM-EDX) microanalysis system. With this system, it was possible to obtain microanalysis spectra in the different samples and to determine their chemical composition.

This phase is concluded with an architectural study of the emerging structures using an unmanned aerial vehicle (UAV) for methodical image capture. The equipment used was a DJI Phantom 2 Vision+ drone that incorporates an FC200 camera with a 1/2.3" sensor and 14 megapixels $(4384 \times 3288)$ of geometric resolution for a field of view of $110^{\circ}$. In the three-dimensional modeling obtained and in the associated planimetries, volumetric and formal characteristics were indicated, as well as data that provide information on the material, construction technique [112-114] and state of conservation.

- Hazard identification phase and associated mapping. The hazard factors affecting the castle and its territorial environment were identified. In the systematization of factors, a protocol was elaborated, including those identified by the National Plan for Disaster Risk Management of Cultural Heritage [115] and the National Plan for Defensive Architecture [60]. The families of risks considered were those related to natural and anthropic phenomena.

A digital mapping of natural hazards was carried out using spatial analysis processesinterpolation, kernel density, extrapolation, intersection and dissolution-based on primary coverage from information sources and secondary risk mapping in macrozoning and microzoning. These data model follows the guidelines of Directive 2007/2/EC of the European Parliament Directive Infrastructure for Spatial Information in Europe (INSPIRE) [116].

- Phase of analysis of the state of conservation and elaboration of pathology maps. The main damages presented by the castle were identified and associated with the hazard factor that produced them. The following groups of pathologies were considered according to their origin: by the action of environmental factors; by the action of biologic agents; by the action of factors of chemical origin; by the action of factors of geological nature and of structural origin. The influence of anthropic hazards was also been taken into account in this analysis. On the planimetries obtained in the architectural study carried out in the previous phase, a general mapping of pathologies (macroscopic) was made. All the points were georeferenced and supported by an orthophotogrammetric image that helped to read the state of degradation of the walls.

- Evaluation of the degree of hazard and vulnerability using the Delphi method and estimation of the global risk. Taking into account that the formula of risk $\mathrm{Ri}=\mathrm{Hi}^{*} \mathrm{Vi}^{*} \mathrm{E}$ (risk $=$ hazard $\times$ 
vulnerability $\times$ exposure), the study aims to know and evaluate the relationship between hazard and vulnerability for each group of risks affecting each asset. Therefore, each hazard is evaluated in particular and its relation to the specific damage it generates in the asset, as well as the intensity with which this damage is produced. The Delphi method was used for the multidimensional evaluation of such intensity [7,117-121]. Several stages were established for its application:

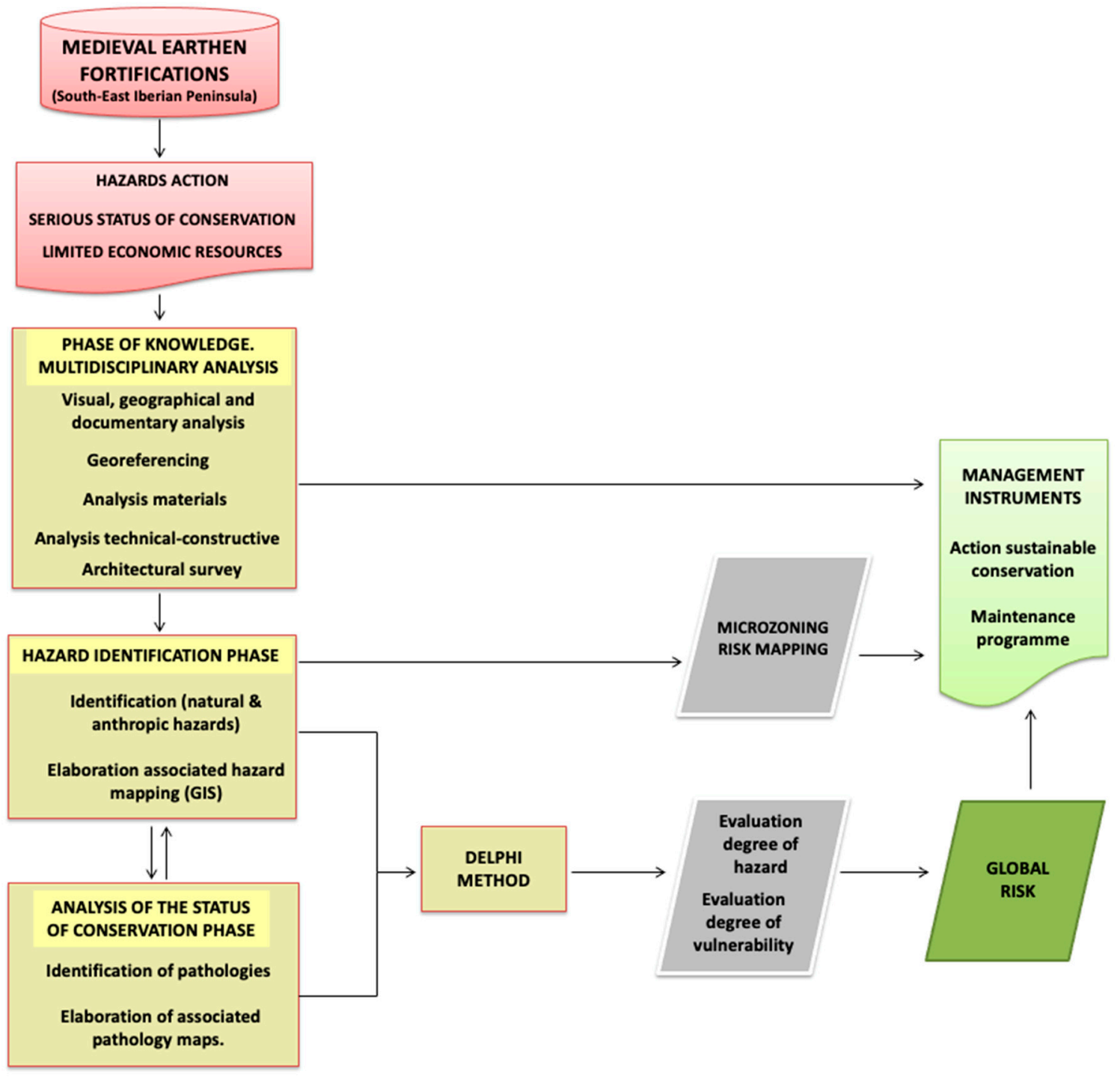

Figure 1. Flow chart showing the phases followed in the study. Source: PREFORTI project.

- Generation of the questionnaire and its completion by a group of experts. The questionnaire was provided to a group of 20 experts. All of them had advanced knowledge related to the territory and the conservation of its cultural heritage. The disciplines chosen were: environmental sciences, history of art, archaeology, architecture, construction, engineering, geology, chemistry, restoration and cultural management.

- Assessment of the degrees of hazard and vulnerability. In the evaluation of the degree of incidence of the different factors of hazard that act on the asset and its environment, variables such as the probability of the risk happening, the consequences that it generates and the possible measures to be adopted for the minimization of the effects were taken into account. For this assessment, each expert, according to their knowledge discipline, was assigned a numerical value to each of the assessable items presented in the questionnaire, establishing a range of assignments between 
zero and five (zero being the non-existence of hazard and five being the highest level of hazard). The same procedure was applied in the assessment of the vulnerability manifested in the castle structures from the evaluation of the existing pathologies. Among the aspects taken into account in its estimation, the decontextualization of the asset, the existence of structural damage, the degree of destruction and the loss of values in the process of adaptation to the territorial context stand out. In assigning a numerical value to each item, the same range was used as before, i.e., between zero and five (zero being the absence of vulnerability and five being the highest level of vulnerability).

Each hazard and vulnerability has a list of indicators that was provided to the evaluators to enable them to carry out the assessment. For the study of vulnerability, lists of the most common pathologies present in medieval earthen fortified structures were generated. Moreover, general damage scales were established to allow their assessment, as already mentioned, in a range of zero to five. In the specific case of structural analysis, the study focused on the structural pathologies listed in. Some damage, such as structural ones, maybe due to a variety of causes. In such cases, the lists of fieldwork for vulnerability already proposed different origins for the same pathology, so that the assessor could establish his assessment directly. This system allowed for the regrouping of structural damage already assessed into its corresponding hazard group. The hazard analysis was carried out directly according to the items that can be seen in. Once the quantitative assessments of hazard and vulnerability was independently established, they were transferred to generating the structural risk values, in this case, distributed at different points in table.

Below, for each category of factors (hazard and vulnerability) the median values of each item and each group were calculated separately. To avoid possible dispersion in the experts' assessment, a second consultation was carried out. For this purpose, a summary of the results obtained from the completion of the previous questionnaire was prepared for them. In this way, they could re-evaluate their opinions in the light of this information, in search of consensus. The purpose of the application of the Delphi method is to obtain a consensus opinion from the group [122].

Once the degree of stability in the responses was achieved, the relative arithmetic average of each hazard and vulnerability group is calculated by obtaining a quotient, between 0 and 5 . Their qualitative rating (also expressed on a scale of 0 to 5 ) is described in Table 1. This assessment was decided upon using the triangulation technique.

Table 1. Correlation of the hazard/vulnerability values obtained. Source: PREFORTI project.

\begin{tabular}{ccc}
\hline Resultant Value & Degree of Hazard/Vulnerability & Estimated Value \\
\hline 0 & 0 & Without hazard/vulnerability \\
$0.05-0.5$ & 1 & Minimum hazard/vulnerability \\
$0.55-1.25$ & 2 & Low hazard/vulnerability \\
$1.30-2.5$ & 3 & Medium hazard/vulnerability \\
$2.55-3.95$ & 4 & High hazard/vulnerability \\
$4-5$ & 5 & Maximum hazard/vulnerability \\
\hline
\end{tabular}

Then the risk calculation formula $\mathrm{Ri}=\mathrm{Hi}^{*} \mathrm{Vi}^{*} \mathrm{E}$ (risk $=$ hazard $\times$ vulnerability $\times$ exposure) was applied. Given that it is related to the BIC (assets of cultural interest), the variable exposure (E) will be the one that presents the structure to the hazard action, regardless of its state of conservation. The Exposure of the structure cannot consider an economic value as a determining factor in the calculation of the risk. When dealing with BIC, the economic value will be equal to 1 . In case the institution in charge of their guardianship wishes to include $\mathrm{E}$ as a variant depending on their economic or social needs, it will be given the appropriate value in each case. In this way, a value is obtained for each hazard group that is in the following range $\mathrm{Ri}[0,25]$.

Finally, the global risk was calculated according to the conditions of hazard/vulnerability and was established by weighing each hazard factor. For this, a weighting of each hazard factor is established 
in which the documentation hazard related have a 30\%, and geographic and utilitarian related hazards have a $50 \%$. The rest of the hazards are valued at $100 \%$ (Table 2):

Table 2. Weighting factor applied. Source: PREFORTI project.

\begin{tabular}{lll}
\hline \multicolumn{1}{c}{ Hazard } & \multicolumn{2}{c}{ Weighting Factor } \\
\hline Document & $\alpha 1$ & 0.3 \\
\hline Geographical & $\alpha 2$ & 0.5 \\
Usage & $\alpha 3$ & \\
\hline Anthropogenic & $\alpha 4$ & \\
Water & $\alpha 5$ & 1 \\
Seaquakes & $\alpha 6$ & \\
wind & $\alpha 7$ & \\
Temperature & $\alpha 8$ & \\
Forest fire & $\alpha 9$ & \\
Geomorphological & $\alpha 10$ &
\end{tabular}

Since anthropic and natural factors are the main ones that compromise the material physical state of the asset, the weight considered for them is $\alpha=1$. Other factors of diverse origin have less weight in this study, $\alpha=0.3$ and $\alpha=0.5$. This is because these factors have fewer incidences on its material deterioration, according to the hazard analysis.

The total risk value is calculated using the following formula:

$$
R=\frac{25}{207.5} \sum_{i=1}^{10} \alpha_{i} R_{i}
$$

Hence, after applying it the conversion is made according to Table 3, obtaining the global risk Factor for the structure under study.

Table 3. Table of correlation of the degree of global risk. Source: PREFORTI project.

\begin{tabular}{ccc}
\hline Points & Risk Level & Estimated Value \\
\hline $0-0.99$ & 0 & Without risk \\
$1-4.99$ & 1 & Minimum risk \\
$5-9.99$ & 2 & Low risk \\
$10-14.99$ & 3 & Medium risk \\
$15-19.99$ & 4 & High risk \\
$20-25$ & 5 & Maximum risk \\
\hline
\end{tabular}

- Systematization of conservation strategies: after obtaining the risk maps and evaluation of the state of conservation of the construction units of the Lojuela Castle, an approach is established to the conservation and maintenance actions to be carried out on the asset and its surroundings. These were organized in three different levels: emergency actions, prevention actions and restoration actions.

Urgent actions: This includes works to be carried out urgently, which are capable of curbing the hazards that compromise the stability of the asset. These actions can be taken on the structure of the castle and/or on the territory.

Prevention actions: These include the works that minimize and/or mitigate the effects of certain hazards. They mainly consist of the availability of mechanisms that can hinder the process.

Restoration actions: They identify processes that contribute to the overall value of the cultural asset. 


\section{Results}

\subsection{Application of the Method. Case Study of the Lojuela Castle}

\subsubsection{Geographical and Geological Contexts}

The Lojuela Fortification (or hișn in Arabic) is located $1.5 \mathrm{~km}$ west of Murchas in the Lecrin municipality of the Granada Province. It occupies an east-southeasterly fertile plain, on the highest elevation of a ravine, which prevails over the Dúrcal river valley to its left (Figure 2). The UTM coordinates of the asset are: X 448598.5; Y 4089107.4; Z $593.57 \mathrm{~m}$ [123].
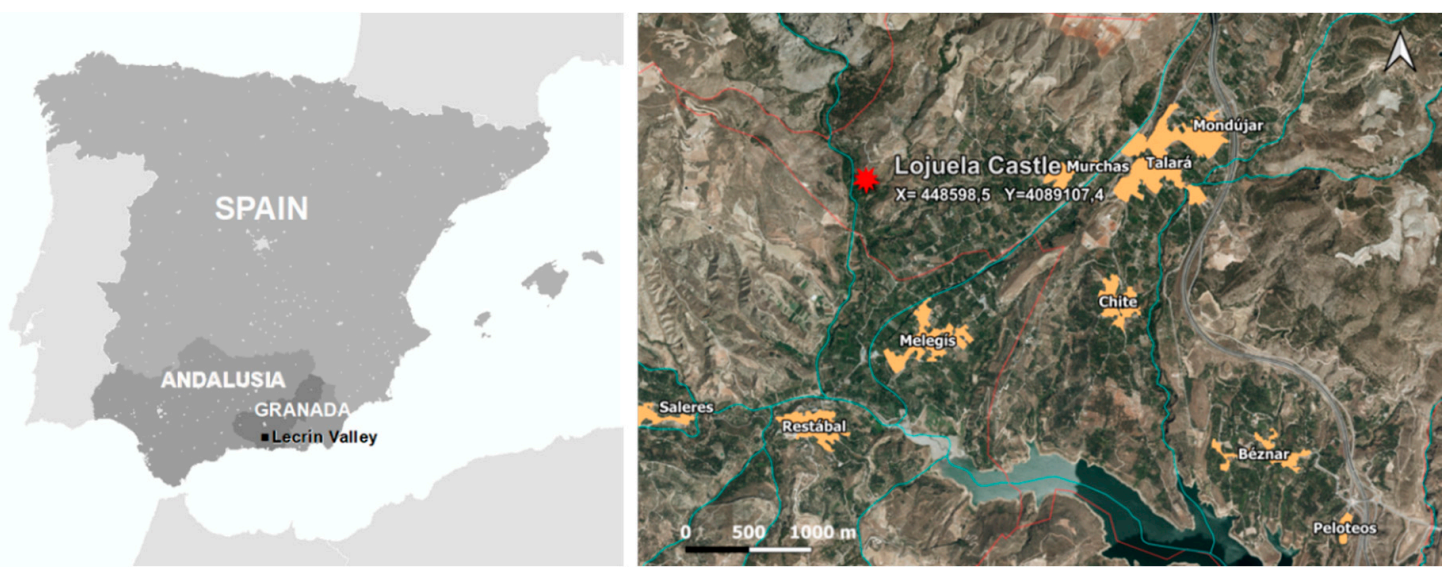

Figure 2. Location map of the province of Granada and orthophotography with the location of the Lojuela Castle. Source: PREFORTI project and own development from Google Earth.

Geologically, three different units of the Alpujarran complex emerge in this area: Los Guajares mantle, La Herradura-Trevenque mantle and Alcazar mantle. Above them, there are sedimentary materials from the Neogene and Quaternary periods. However, in this specific place, the Alpujarran complex is formed by two mantles that run in a northwest-east direction (La Herradura-Trevenque mantle and Los Guajares mantle), with outcrops of the Alcazar mantle to the southeast of Murchas.

The Lojuela Castle is built on Miocene terrain whose stratigraphy, from bottom to top, is formed by a basal conglomerate, followed by silts and sands. Above them there is a series formed by bioclastic limestones; sands and conglomerates, sandstones and levels with oysters and corals [124].

\subsubsection{Identification, Heritage Protection and Planning}

The Lojuela Castle has been declared an Asset of Cultural Interest in the immovable asset category and in the monument classifications, in accordance with the Law of Spanish Historical Heritage [74]. It is registered in the General Catalog of Andalusian Historical Heritage in accordance with Law of Historical Heritage of Andalusia [75]. Local protection is granted as per the Subsidiary Regulations of Lecrin [125].

Its protected area has not been delimited. It is only protected by the Law of Historical Heritage of Andalusia, which refers to a general protection of its environment of $200 \mathrm{~m}$ [75].

\subsubsection{Historical Context}

Lojuela is no longer inhabited, but it is believed that its populace would have been found in the environs of what is currently known as the "thrashing circle of Lojuela". Murchas is barely mentioned by Muslim authors or by Christian chroniclers, perhaps because this and other communities in the area were known collectively as "The Lecrin Valley". It was Luis del Mármol Carvajal who, in reference to the occupation of Tablate in the Moorish uprising of the late sixteenth century, cites the population 
of Mulchas specifically in his description of this region's boundaries [79]. The castle pertained to the Loxuela o Luxar farmstead, which was probably annexed to Murchas, but with its own administration. The Marqués de la Ensenada land registry makes reference to the castle, locating it in the so-called Pago de la Ojuela (Figure 3). More recently it was connected to the first Arab caliphate [80,123].

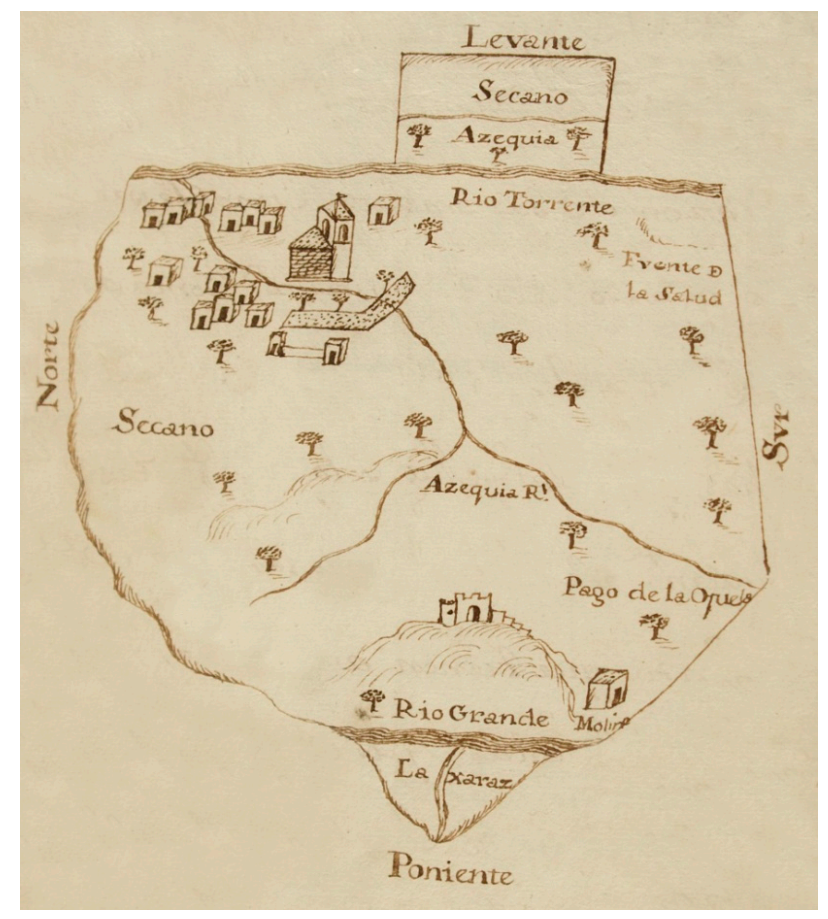

Figure 3. Map of Murchas where the fortified structure is sited (without scale). Source: Marqués de la Ensenada Land Registry (1751-1758). Arhivo Histórico Provincial de Granada [126].

\subsubsection{Description of the Lojuela Castle Architectonics}

Currently the visible structures of the fortification (hisn) extend along the slope of the ravine, with the main tower located on the summit of the hill. The studies carried out originally concluded that it comprised at least two areas: one delineated by the walled enclosure and one in its interior where the remains of structures can still be seen, including a large tower (Figure 4). The site has a polygonal arrangement and access is from the north section, where vestiges of the bastion which defended it can be found (Figure 5).

Adjoining this entrance area and extending towards the east, a significant stretch of the wall over six meters in height and 44 meters in length can be seen. The construction technique used was cladded rammed earth. This was mounted on a stone slab of the same thickness and graduated in line with the steep slope of the land (Figure 6). The stonework served as a foundation, to level the rammed-earth formwork and in order to prevent rising damp due to capillarity. The exterior facing remains in a better condition than that on the interior face, which has practically disappeared. The graded crown on the stretch of wall is covered by a thick layer of restorative mortar, which has the effect of protecting it from rainwater damage and of the pavement of the adarve [79].

The parapet rested on this level, possibly with merlons, although no remains of these have been found. A guard rail was located on the exterior part of the wall, the paving of which sloped towards the interior in order to allow for water runoff from the ramparts, a fact which has caused greater degradation to the facing $[80,123]$.

Similarly, characterized remnants of the wall are found to the north, south and southeast. These latter ones have served as retaining walls for the earth fill in its interior. The western face of the wall was weaker, given that the rock itself acted as a natural defense. A large number of levels are visible 
along the slope of the hill. Among them, some stone walls and others made of rammed earth form part of the internal structure of the fortification [81]. Low-lying remains of the walls which conform to the successive terraces can be found distributed throughout the enclosure.

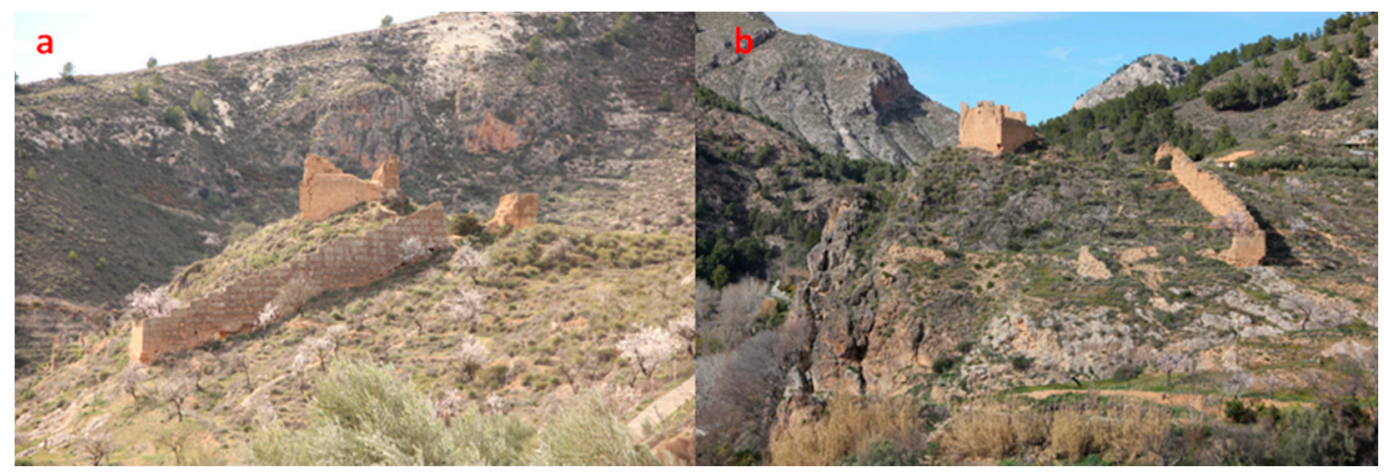

Figure 4. View of the remains of Lojuela Castle from its (a) eastern and (b) southern sides. Source: PREFORTI project.
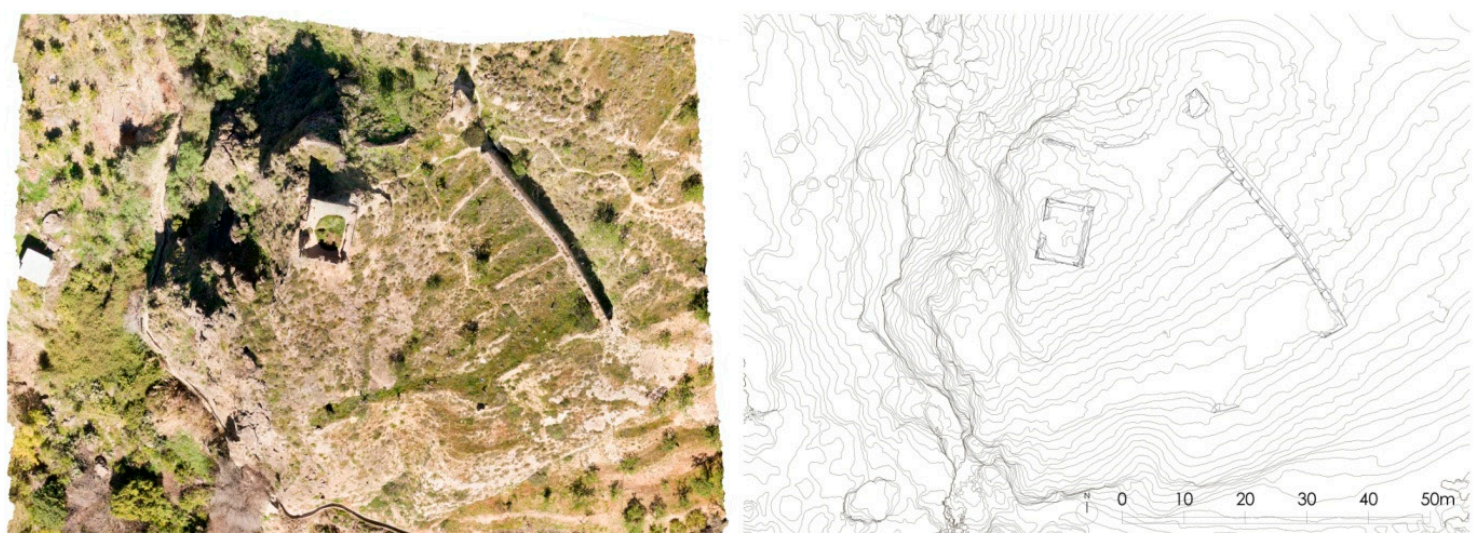

Figure 5. Orthophotography and planimetry of Lojuela Castle remains. Source: PREFORTI project.
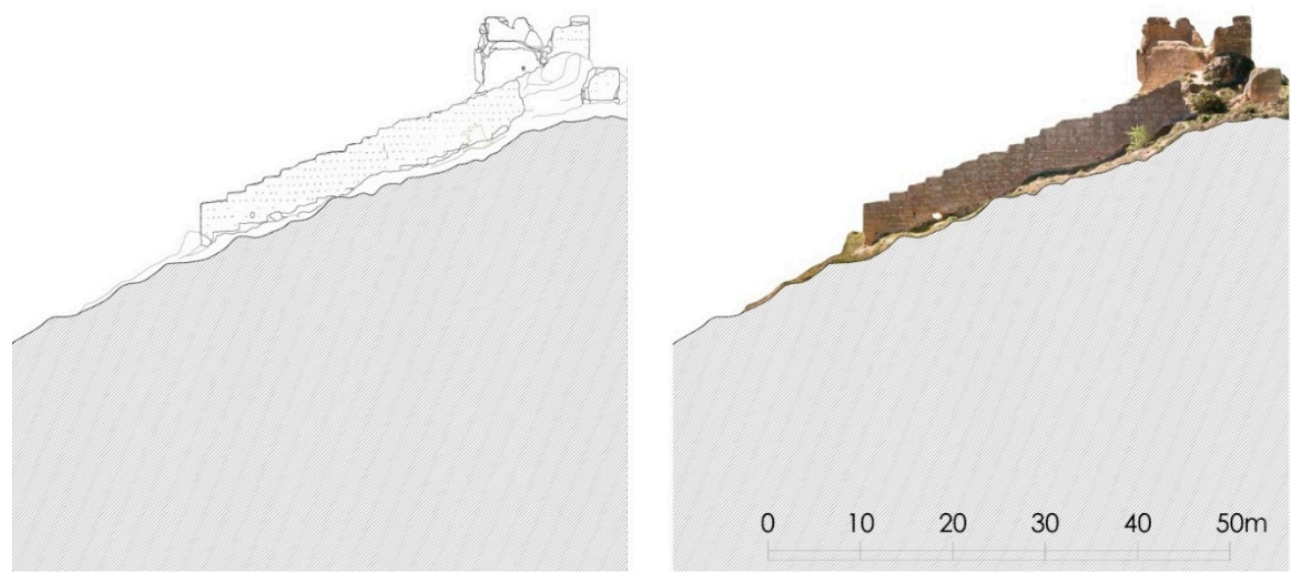

Figure 6. Orthophotography and planimetry of the east elevation of Lojuela Castle, located on the promontory. Source: PREFORTI project.

On a cloth of the outer wall, at the lower part, there are traces of the ropes that could have been used in the construction, possibly to define the blocks that would simulate ashlars.

The tower is located on the upper section, from which the ravine over the Izbor river valley can be seen. Its measurements are $9.85 \times 7.85 \mathrm{~m}$. The largest sides are on the east and west. It reaches 
four meters in height. It was constructed using rammed-earth walls, low in lime and included some stone flakes [127]. It was raised on a stonework platform and fixed in place with mortar and plaster, which caused recesses in the stone [81]. The corners are reinforced with ashlars, which are more visible in the southeast corner. It still retains remnants of its terracotta colored exterior facing. The separation between the formwork drawers $(0.80 \mathrm{~m})$ is clearly visible.

There may be a water reservoir in the interior of the stone platform, but this cannot be confirmed due to a layer of fill and vegetation above it. As well as the structures of the enclosure, there are the remains of walls which conform to the terracing of the land. They were possibly living quarters for the garrison or served as temporary refuge for the population [80].

\subsubsection{Description of the Materials}

These were assessed by taking different samples from the surface of the cladding and stretches of the wall (Figure 7). The results indicate that: as regards the wall, its main body was found to be principally lime-based. It consists of mortar made by mixing lime and clay. Siliceous and carbonated aggregates were used, with the granulometry revealing a range of sizes from gravel to sand. The siliceous aggregates are comprised of quartz, muscovite, chamosite and feldspar. The carbonated aggregates are composed of dolomite and possibly, calcite [124].

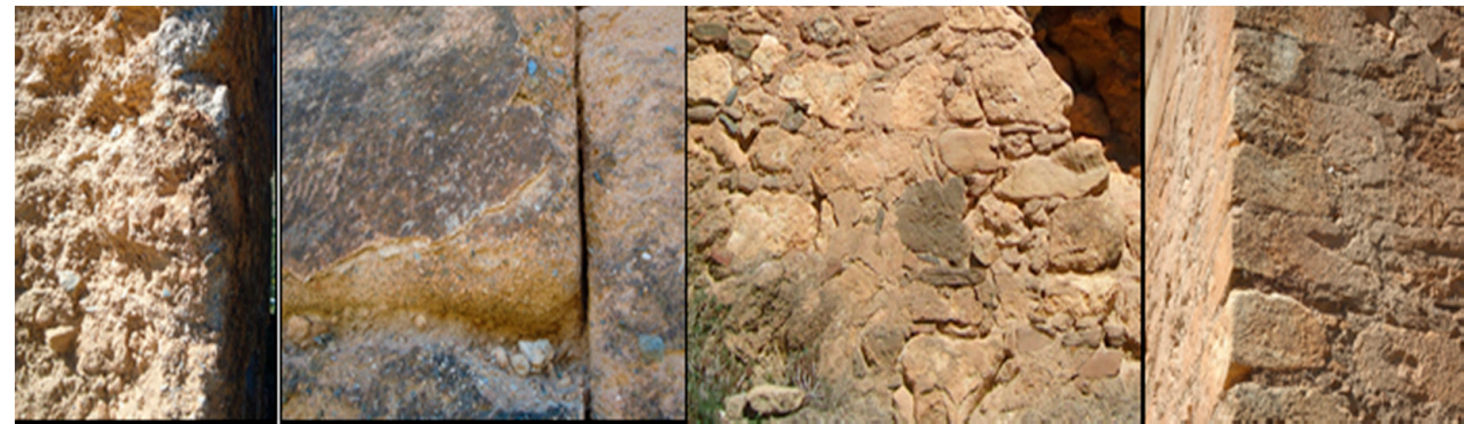

Figure 7. Materials used in the construction of Lojuela Castle (without scale). Source: PREFORTI project.

The XRD analyses carried out on the sample of the calicostrated wall mass detected that the matrix is mainly calcitic. It established that the construction material—as detailed before-is a mortar made with a mixture of lime and clay, in which siliceous and carbonated aggregates were used, with serial grain size from gravel to sand (Figure 8).

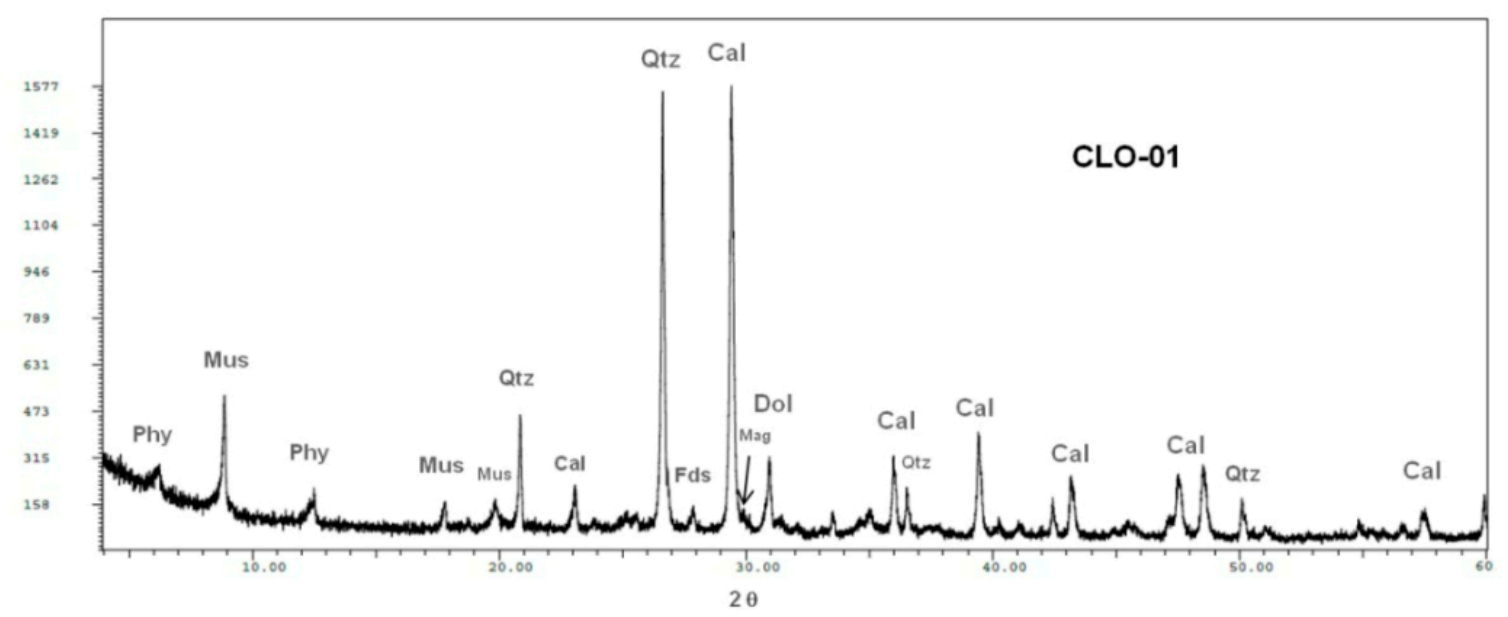

Figure 8. X-ray diffractogram of the sample. Source: PREFORTI project and TESELA S.L. 
In relation to the coping, its aggregates would have contained fragments of quartz-schists, schists with garnets, black graphite schists, limestone and dolomite. Siliceous aggregates have characteristics similar to those of the basal mantle in the Guájares, west of the castle. The carbonated aggregates are similar to the materials in the mantles of the Alpujarran complex. The rock fragments which were used as aggregates are congruent with the geological context of the castle [124].

The mortars used for the coping are calcitic, with a lime/aggregate ratio of approximately 1:3. As for the masonry cladding, the mortar is similar to those mentioned previously although the mortar mix is made from calcitic lime, with a lime/aggregate ratio of approximately 1:2. The cladding was a mineralogical composition which is similar to the coping and mortar, although the grayish hue of the mortar and the cement dye test indicate the use of Portland cement in its composition [124].

The study carried out by scanning electron microscopy with EDX microanalysis and from the spectra obtained determined that the composition of the matrix of the rammed-earth crust is calcitic. Mica (Muscovite) crystals were also observed wrapped in the matrix. The presence of roots of the natural patina was verified. It generates biodeterioration in the sample since they penetrate inside the crust mortar (Figure 9). In the matrix of the rammed-earth mass, siliceous aggregates are observed enclosed within a microcrystalline matrix formed by a mixture of calcite and illite [124].
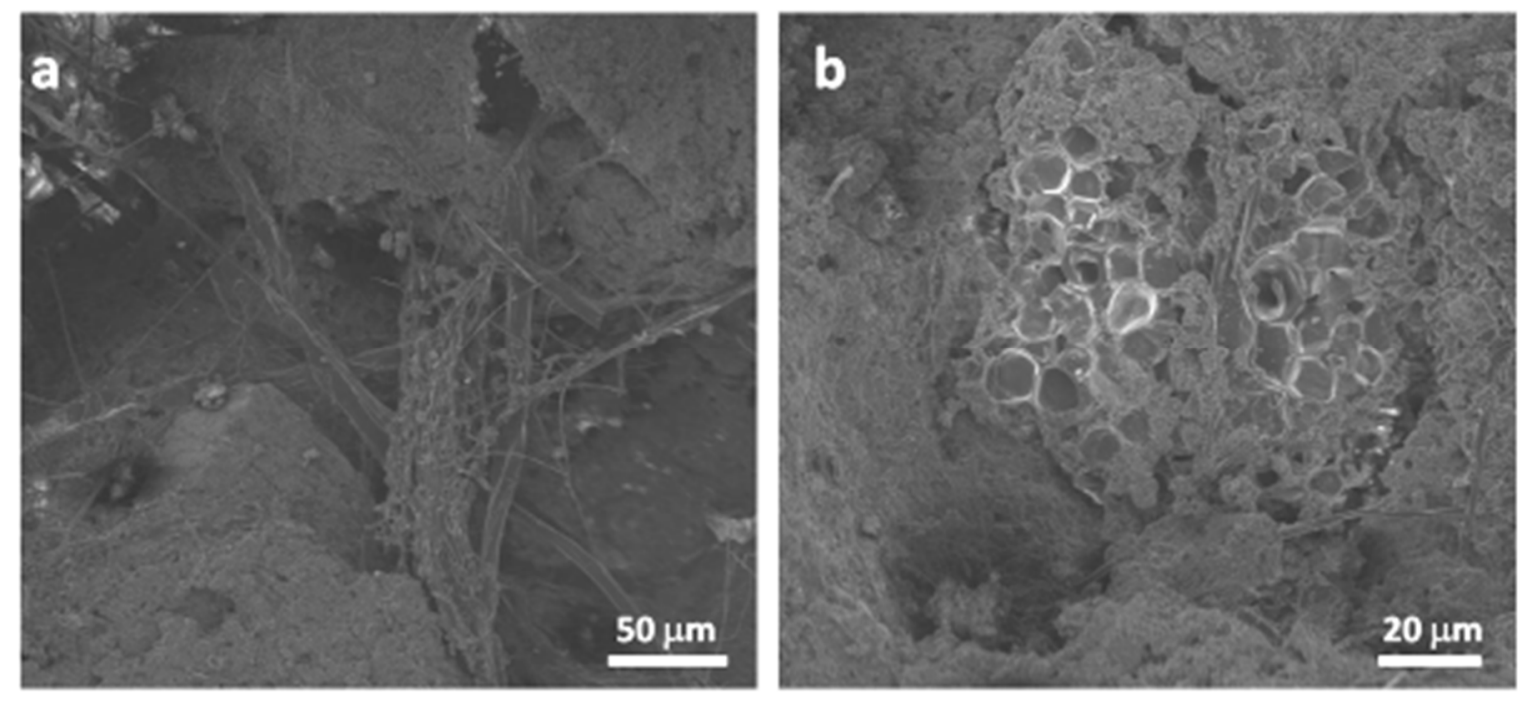

Figure 9. SEM microphotographs of secondary electrons of the crust. Presence of (a) roots and (b) lichens from the natural patina is visible. Source: PREFORTI project and TESELA S.L.

\subsubsection{Technical-Constructive Description}

The main building technique used was of cladded rammed earth raised on stone platforms with reinforcements to the corners using ashlars. It was made using a series of formwork boxes which had a total height of between 76 and 80 centimeters for the tower. The limestone casting segments are approximately seven centimeters thick on average. The support beams for the upper boxes were not transversal and each section was $7 \times 3$ centimeters on average. The putlog holes were covered with a mortar similar to the coping and were levelled to produce an unbroken finish. This series of five vertically stacked boxes was reinforced with stone, and the entire structure of the wall was raised on a strong, irregular grouted stone base and coated with mortar.

The stretches of wall were made using rammed-earth low in lime and were raised on a graduated stone base made from slabs and large stones grouted with mortar, conforming to the significant slope of the land and were finished to the same height as the tabiyas (the Arabic term for the shaped formwork) of the wall. These stones were set and levelled using large sized debris and acted as a base and leveler of the rammed-earth formwork. Remains of the wooden beams still exist as well as numerous indents 
from the fabric to which the slats were nailed. Furthermore, visible are the prints from cord which was possibly used during construction to measure the blocks which were to form the ashlars.

\subsection{Risks and Pathologic Analysis}

\subsubsection{Main Hazards Affecting the Lojuela Castle}

Once the asset was positioned in the territory and after being related to the existing hazard maps in the geographical area of the province of Granada (Spain), it was determined that the main hazards affecting the Lojuela Castle are:

Of a natural character: the action of water in its various manifestations (capillarity, ambient humidity, rain, floods and snowfalls); the action of winds, the dominant ones being those from the northeast; the action of lightning; the action of high and low temperatures and ice; forest fires due to high seasonal temperatures and/or the incidence of lightning in electric storms and those of geomorphological action including earthquake, landslide, clay expansivity and steep slope.

Of an anthropic character: those related to the abandonment of the cultural asset, the lack of documentation, those of a geographical nature due to the disappearance of historical boundaries, the disappearance of the original defensive use and the lack of attention and maintenance of this structure by the competent administrations have been important. They have aggravated the situation of instability in recent years and risking its survival. To these must be added the action of acts of vandalism and those caused by technical errors in restoration when modern cement mortars are used. Together with the above, the use of the land in the adjacent area through agricultural use has terraced it, risking the bases of the structure.

\subsubsection{State of Conservation and Damage Maps of the Lojuela Castle}

The series of pathologies affecting earthen defensive structures is very wide and was studied in a systematized way (Table 4). They were considered to propose precise action protocols. In this context, it was convenient to sectorize the damage into three areas: material, structure and surroundings.

Material: Intrinsic factors which have implications on the basis of their chemical, mineralogical and petrographic composition were observed to produce pathologies of disintegration and biodeterioration. Changes to the patina on the coping appear to be natural and due to the accumulation of clay minerals on its surface, causing it to separate. The masonry cladding shows a patina due to the clays accumulating, causing deterioration on its surface [124].

Structure: the site is greatly affected; in particular, the body of the tower is seriously threatened with falling into ruin. Significant vertical cracks and at a $45^{\circ}$ due to a misplacement of the end of the wall are compromising the stability of the site, in particular the eastern and southern sides. Although the root cause may be ground movement, another contributing factor is the significant erosion to the lower part of the stonework. It is causing the southeast corner of the structure to act as a cantilever. This erosion also affects the center of the defensive perimeter to the north. In this part, voids have appeared of sufficient size to run through to both sides of the wall. Fragments of rammed earth which have either detached or are in the process of detaching can be found in the site's surroundings. The loss of geometry to these two structures is significant as the cladding on the tower has disappeared, as have some formwork box sections. Almost all of the tower's levels were lost, with only part of the first level remaining. However, the eastern stretch of wall is preserved at the height of its ramparts.

Surroundings: The plot on which the castle is located is classified as agricultural land and the planting of different tree species, almond, encourages land clearance and terracing, thus increasing the risk that any remains from the site which were scattered will be lost. Similarly, as it was left abandoned, vegetation has been growing excessively in the surrounding area. 
Table 4. Pathologic analysis structure of Lojuela Castle. Source: PREFORTI project.

\begin{tabular}{|c|c|c|}
\hline Hazard Group & Pathologies & Present on the Asset \\
\hline \multirow{8}{*}{ Environmental damage } & Loss of cladding & $\mathrm{X}$ \\
\hline & Surface erosion & $\mathrm{x}$ \\
\hline & Loss of facing & $x$ \\
\hline & Volumetric loss & $x$ \\
\hline & Disintegration & $\mathrm{x}$ \\
\hline & Piece breakage & $\mathrm{x}$ \\
\hline & Dirt & $\mathrm{x}$ \\
\hline & Exfoliation & $x$ \\
\hline \multirow{5}{*}{$\begin{array}{l}\text { Damage caused by } \\
\text { organic agents }\end{array}$} & Lichen, moss, fungi & $\mathrm{x}$ \\
\hline & Moderate vegetation & $\mathrm{x}$ \\
\hline & Excessive vegetation & $\mathrm{x}$ \\
\hline & Detritus & $\mathrm{x}$ \\
\hline & Nestling & \\
\hline \multirow{10}{*}{$\begin{array}{l}\text { Damage of structural } \\
\text { origin }\end{array}$} & Due to incompatibility of deformation & $\mathrm{x}$ \\
\hline & Damage due to a concentration of stress in deformable elements & $x$ \\
\hline & Disintegration or hazard of detachment of the rammed-earth crown & $x$ \\
\hline & Cracks and fissures & $\mathrm{x}$ \\
\hline & Collapse & $x$ \\
\hline & Settlement & $x$ \\
\hline & Displacement & $x$ \\
\hline & Discard & $x$ \\
\hline & Stability issues & $\mathrm{x}$ \\
\hline & Loss of geometry & $\mathrm{x}$ \\
\hline \multirow{4}{*}{ Water damage } & $\begin{array}{l}\text { Chromatic change } \\
\text { precipitation runoff marks }\end{array}$ & $\mathrm{x}$ \\
\hline & Atmospheric humidity & $\mathrm{x}$ \\
\hline & Humidity due to capillarity & \\
\hline & Humidity due to filtration & \\
\hline \multirow{3}{*}{$\begin{array}{l}\text { Damage of chemical } \\
\text { origin }\end{array}$} & Blackened coping & $x$ \\
\hline & Chromatic changes & \\
\hline & Efflorescence & \\
\hline \multirow{2}{*}{$\begin{array}{l}\text { Damage caused by } \\
\text { geological agents }\end{array}$} & Slope movement & \\
\hline & Rock fracture & $x$ \\
\hline \multirow{5}{*}{$\begin{array}{l}\text { Damage caused by urban } \\
\text { or environmental assault }\end{array}$} & Terraced construction & \\
\hline & Overlapping construction & \\
\hline & Environmental degradation & \\
\hline & Loss of traditional landscape & \\
\hline & Distortion of the horizon line & \\
\hline \multirow{9}{*}{$\begin{array}{l}\text { Damage due to improper } \\
\text { repair or restoration }\end{array}$} & Differing masonry & \\
\hline & Cladding with cement/lime/sand mix mortar & $x$ \\
\hline & Plastering cement & \\
\hline & Underpinning & \\
\hline & Appearance of gaps & \\
\hline & Filling & \\
\hline & Incompatible material & \\
\hline & Incompatible technique & \\
\hline & Reinforcement of slopes or against aggressive soil & \\
\hline \multirow{5}{*}{$\begin{array}{l}\text { Damage caused by urban } \\
\text { or environmental assault }\end{array}$} & Terraced construction & \\
\hline & Overlapping construction & \\
\hline & Environmental degradation & \\
\hline & Loss of traditional landscape & \\
\hline & Distortion of the horizon line & \\
\hline
\end{tabular}

The major pathologies it presents are shown in Figures 10 and 11:

- Environmental damage: the most notable is associated with the presence of dirt, the existence of surface, medium and deep erosion of the different parts of the wall. Moreover, material gaps are resulting from the loss of material accompanied by generalized surface exfoliation (Table 4);

- Damage produced by the action of water: it has produced an intense washing of the material and decohesion; 
- Damage produced by organic agents: manifested in the appearance of microflora, phanerogamic vegetation and medium vegetation;

- Structural damage: has produced large cracks mainly in the tower and fissures underlying the base of walls; The crowns of the rammed-earth walls have been broken up. The walls have been moved from their initial position;

- Damage of anthropic origin: hollows have been created in the rammed-earth walls to varying degrees;

- Damage from incompatible restorations: due to the incorporation of Portland cement mortars covering the wall crowns;

- Damage due to urban and environmental aggression: as a result of agricultural use of the environment with the removal of material of the lower parts of the wall and terracing of the land. Almond tree plantation.

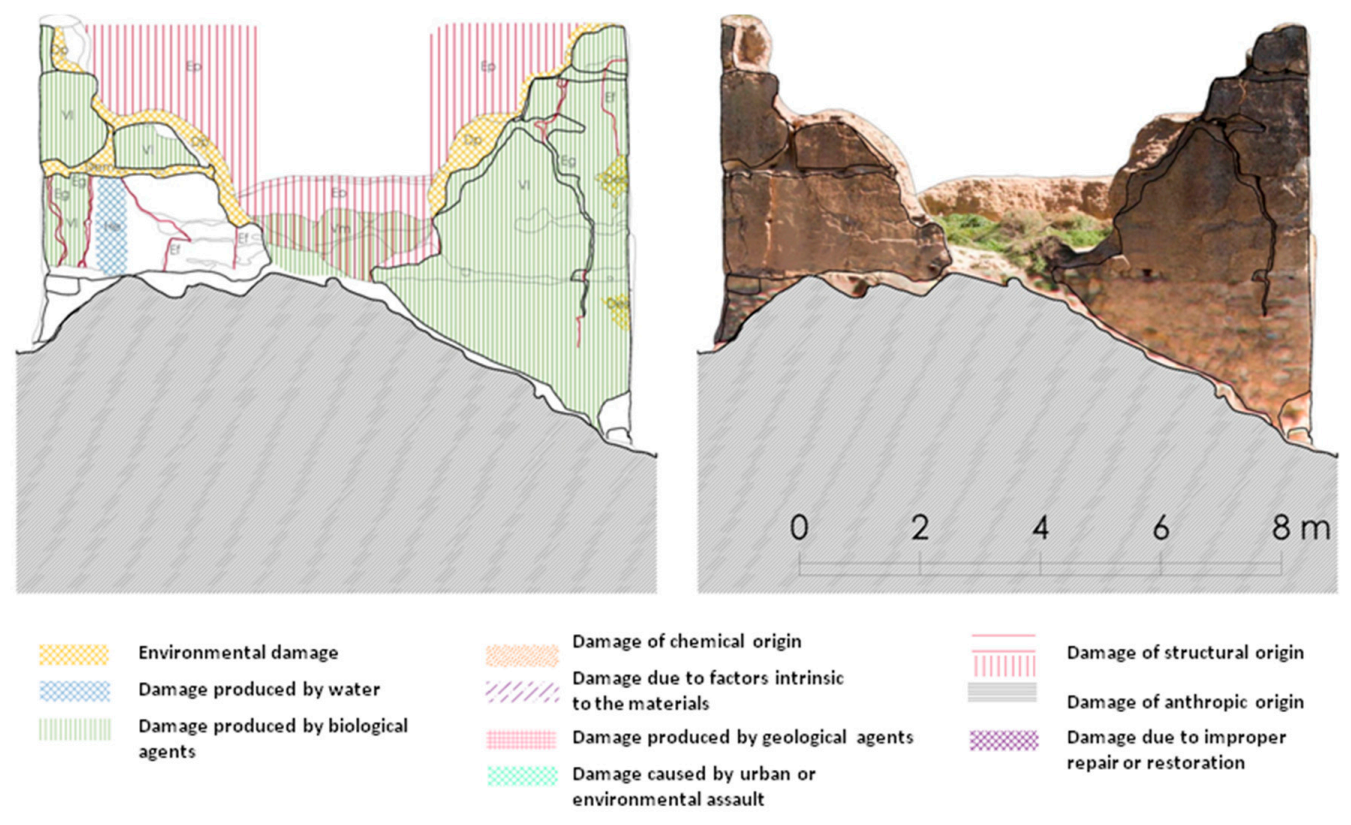

Figure 10. Pathologic analysis of the elevations of the north and west towers. Source: PREFORTI project.
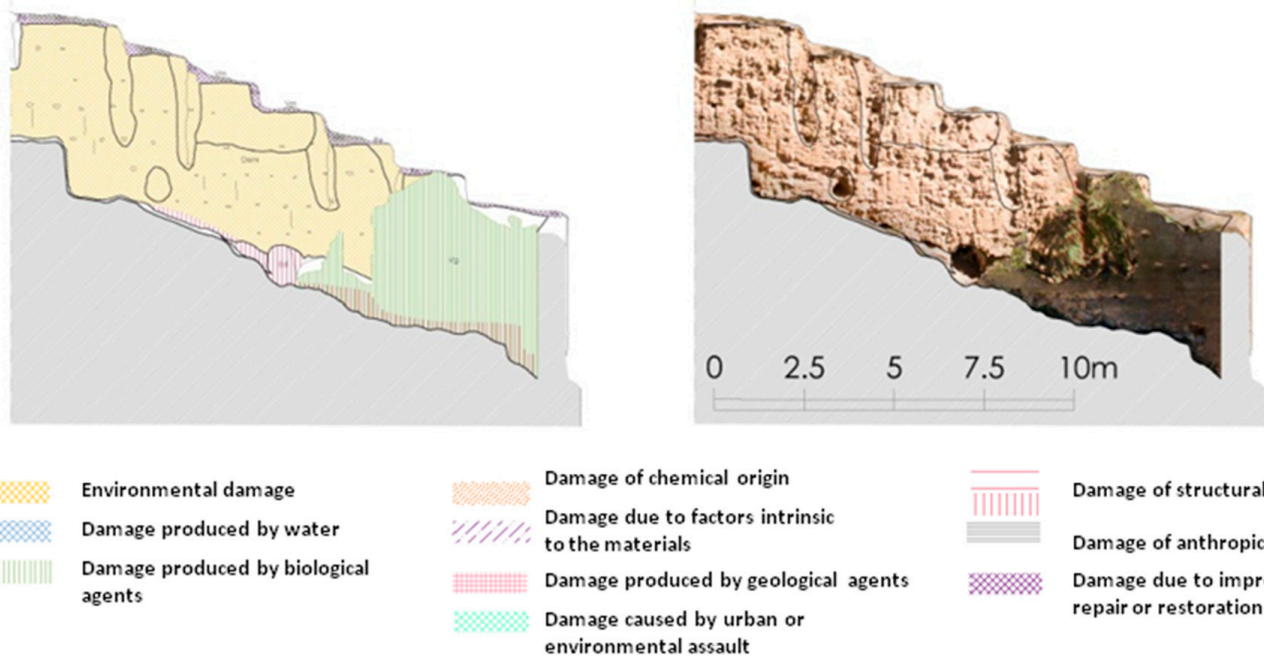

Damage of structural origin Damage of anthropic origin Damage due to improper repair or restoration

Figure 11. Pathologic analysis of the wall. Source: PREFORTI project. 


\subsection{Risk and Pathologic Analysis}

This analysis requires that the categorization protocol created by the project via schematic tables for the full range of risks is used (Figure 12). This is commensurate with the actual conditions of the earthen defensive heritage as it utilizes the system provided by the National Emergency Risk Management Plan for Cultural Heritage [115] and the National Plan for Defensive architecture [60]. These hazards were divided into natural and anthropic. The first ones are related to the action of water, seaquakes, lightning, wind, temperature and geomorphological; while the second ones are those related to documentation, geography and usage together with those related to a lack of maintenance and incorrect conservation and/or restoration efforts. Subsequently, these hazards are linked to the implications for and/or damage they have on the structures, in order to draw up a specific damage map for this cultural asset.

\begin{tabular}{|c|c|c|c|}
\hline HAZARD: & $\begin{array}{ll}\mathbf{H} & \mathbf{R} \\
3 & 12\end{array}$ & PATHOLOGIES: & $\mathbf{v}$ \\
\hline $\begin{array}{l}\text { DOCUMENT } \\
\text { Lack of historical documentation }\end{array}$ & 3 & Loss of heritage value & 3 \\
\hline Planimetric actual state & 0 & & \\
\hline Archaeological information & 3 & & \\
\hline GEOGRAPHICAL & 110 & & 0 \\
\hline Changes in environmental conditions & 0 & Loss of its perceived location and & 0 \\
\hline Visual invasion due to infrastructure & 0 & function & \\
\hline Disappearance of border lines & 1 & Loss of viewsheds & 0 \\
\hline 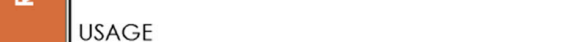 & 312 & & \\
\hline Disappearance of original use & 5 & Devaluation of adaptive processes & 3 \\
\hline Appearance of new uses & 0 & & \\
\hline ANTHROPOGENICS & 312 & & 4 \\
\hline Due to negligence & 4 & Fire & 2 \\
\hline Lack of maintenance & 4 & Flood & 0 \\
\hline Historical conflict & 2 & Proliferation of vegetation & 4 \\
\hline Vandalism, sabotage, terrorism, theft & 3 & Greater or lesser destruction of the structure & 5 \\
\hline Technical errors in restoration and & & Burglary & 0 \\
\hline maintenance & 2 & Structural damage & 5 \\
\hline Urban pressures & 2 & Decontextualization of the structure & $\overline{2}$ \\
\hline Chemical risk (polluted environment, & & Disappearance of elements & \\
\hline transport of dangerous godos) & 0 & Surface or deep chemical deterioration & 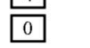 \\
\hline NATURAL RISK & & & \\
\hline WATER: & 312 & & 4 \\
\hline Humidity due to capillarity & 2 & Flood & 0 \\
\hline Atmospheric humidity and / or precipitation & 4 & Surface deterioration & 0 \\
\hline Flood & 0 & Proliferation of fungi, lichen & 4 \\
\hline Snow & 3 & Material disaggregation & $\frac{3}{3}$ \\
\hline & & Structural deterioration & 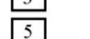 \\
\hline SEAQUAKES - actions of the sea & 00 & Discard & 3 \\
\hline & 0 & Detachment & 3 \\
\hline WIND & 412 & Collapse & 5 \\
\hline Hurricanes & $\begin{array}{ll}0 \\
4\end{array}$ & Dirt & \\
\hline Exposure to winds & 4 & & \\
\hline Lightning & 4 & & \\
\hline TEMPERATURE: & 416 & & \\
\hline Ice & 3 & & \\
\hline High and low temperatures & 3 & & \\
\hline FOREST FIRES & 36 & & 2 \\
\hline Fire & 2 & Calcination of cladding / fragmentation & 1 \\
\hline GEOMORPHOLOGICAL & 315 & & 5 \\
\hline Seismic & 3 & Structural instability & 5 \\
\hline Landslide & 2 & Slope movement & 3 \\
\hline Clay expansivity & 0 & Rock breakage / soil dilution & 4 \\
\hline Steep slopes & 4 & & \\
\hline
\end{tabular}

Figure 12. Risk factors analysis structure of Lojuela Castle. Source: PREFORTI project. 
As it has been explained before, the Delphi method [117-119,128,129] was used for the calculation. In this method, a numeric value of between zero and five, where zero is no risk and five is the greatest risk, according to the severity of each risk and the implication that it has for the structure, was assigned. As can be seen in the following Figure 12, the scores obtained for each class of hazard are different. The scores were calculated from the average for each class of effects, grouped by hazard, according to the risk formula mentioned before $\mathrm{Ri}=\mathrm{Hi}^{*} \mathrm{Vi}^{*} \mathrm{E}$ (risk $=$ hazard $\times$ vulnerability $\times$ exposure).

Given that it is related to the BIC (assets of cultural interest), the variable exposure (E) was considered value to be equal to 1 . The value obtained for each hazard group is in the range $\mathrm{Ri}[0,25]$ (Figure 12). In the following graph, you can see the incidence of risk on the Lojuela Castle according to hazard and vulnerability to risk factors (Figure 13).

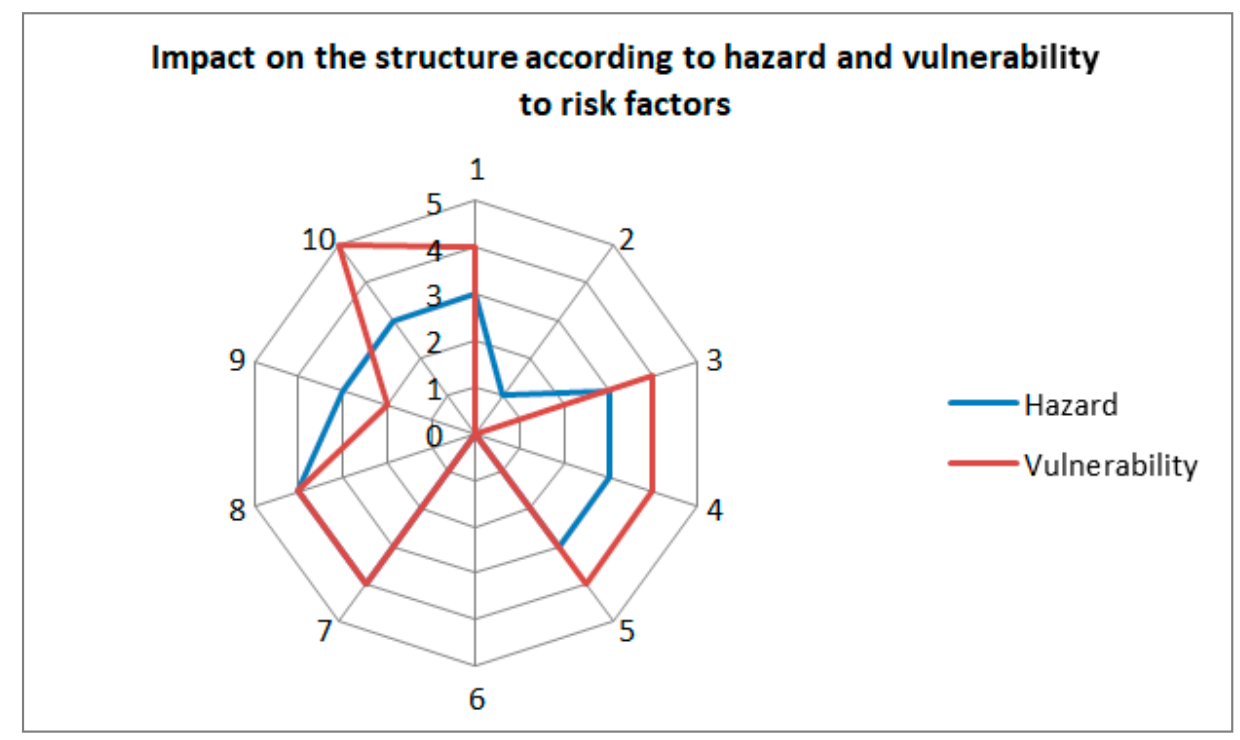

Figure 13. Graphic of impact on the structure according to hazard and vulnerability to risk factors. 1-documentary; 2-geographic; 3-usage; 4 anthropic; 5-water; 6-sea quakes; 7 wind; 8-temperature; 9-forest fire; 10-geomorphological. Source: PREFORTI project.

Finally, the calculation of the global risk of the structure in relation to the general conditions of hazard and vulnerability is presented, establishing the weighting of each hazard factor according to the weights indicated in Table 2. The total risk value is calculated using the formula mentioned above, in Section 3, dedicated to the methodology.

The obtained score for risk is 10.38 adjusted according to the conversion table (Table 2) for the Lojuela Castle gives a degree of global risk 3, which is a medium risk.

\subsection{Basic Conservation Actions}

Once known and considered which factors had more incidence in the state of conservation of the rammed-earth structures of the castle under study, an approach to some of the sustainable action strategies with low economic impact was presented. They constituted a first approach to preventive conservation for the Lojuela Castle and its surroundings [8]. These were developed by which the priorities can be identified across a three-tiered hierarchical scale.

- Urgent actions

- $\quad$ Apply limestone to the tower and stretches of the walls;

- $\quad$ Fill the cracks on the facing thereby stabilizing its position, with repair to the southeast corner of the tower is particularly urgent;

- $\quad$ Reinforce the cladding; 
- $\quad$ Mass volume application with lime mortars where there is a danger of structural imbalance.

- Preventive actions

- $\quad$ Consolidate the facing by inorganic consolidants and lime water spray in several layers;

- $\quad$ Seal the contours of crusts or surface layer;

- $\quad$ Apply compounds based on ethyl silicate punctually in areas that can be stabilized for subsequent sealing;

- $\quad$ Remedy the humidity due to capillarity by applying drainage solutions at the base of the walls;

- $\quad$ Conduct archaeological studies of the monument and environment;

- $\quad$ Repair gaps using lime mortars in small gaps;

- $\quad$ Seal with lime mortars based on clean silica and lime sand;

- $\quad$ Apply herbicides.

- $\quad$ Restoration actions

- $\quad$ Clean the facing by hand using brushes, spatulas or soft nylon brushes;

- $\quad$ Clean the facing by mechanical means using dry suction and blowing techniques so as not to damage the protective crust of the rammed earth;

- $\quad$ Conduct archaeological studies of the surroundings;

- Vegetation control by applying herbicides and clearing of invasive vegetation.

\section{Discussion}

The overlapping of the location of the castle structures on the territory with the main hazards and their multidisciplinary analytical assessment through the application of the Delphi method has shown how and with what intensity the main natural hazards to which the defensive structure is exposed have affected its state of degradation.

The use of current geographical information sources and spatial data infrastructures to identify and collect, at different scales, the variables that characterize each of the risk factors studied has greatly facilitated the implementation of a Geographical Information System and allowed the use of its great potential for geoprocessing information. Interpolation methods, distance analysis or cartography derived from digital terrain models captured with Lidar technology, allow a valuable approach to the territorial reality that supports each of the elements inventoried and the risks to which they are exposed.

Once the georeferenced database was implemented, the study of the assets that make up the defensive land heritage found throughout the southeast of the Iberian Peninsula can be approached from a geographical and territorial point of view. The risk map that is derived allows a detailed analysis of the damage maps to evaluate the risk. Part of this process involves the consultation of microzoned maps to derive a territorial model of each natural or anthropogenic hazards being examined. This change of scale is essential for the subsequent identification of correlations between territorial variables, risk maps and detected pathologies. A combined analysis of the damage maps and the risk maps allows conclusions to be drawn about the real consequences of each risk for a particular heritage asset.

In this way, it can be seen that natural hazards are more closely associated with the pathologies identified in the Lojuela Castle, namely a medium rate of precipitation in conjunction with moderate northeast winds, as well as average relative humidity (Figures 14 and 15). Water and humidity filtrations through cracks, fissures and wall crowns have deconstructed the masses at an average level and have caused a high degree of stains due to runoff and the dragging of dirt on the wall fronts. To the above, the high presence of biodeterioration-elevations with less sunshine-must be added. Other factors such as sunshine, temperature or ice, contribute to the medium degree to the deterioration of the asset. The combined action of them together with the wind has caused the erosion of crusts that 
were intensifying until affecting the masses to a high degree, putting the property at serious structural risk. Less relevant were the damages derived from a chemical origin.

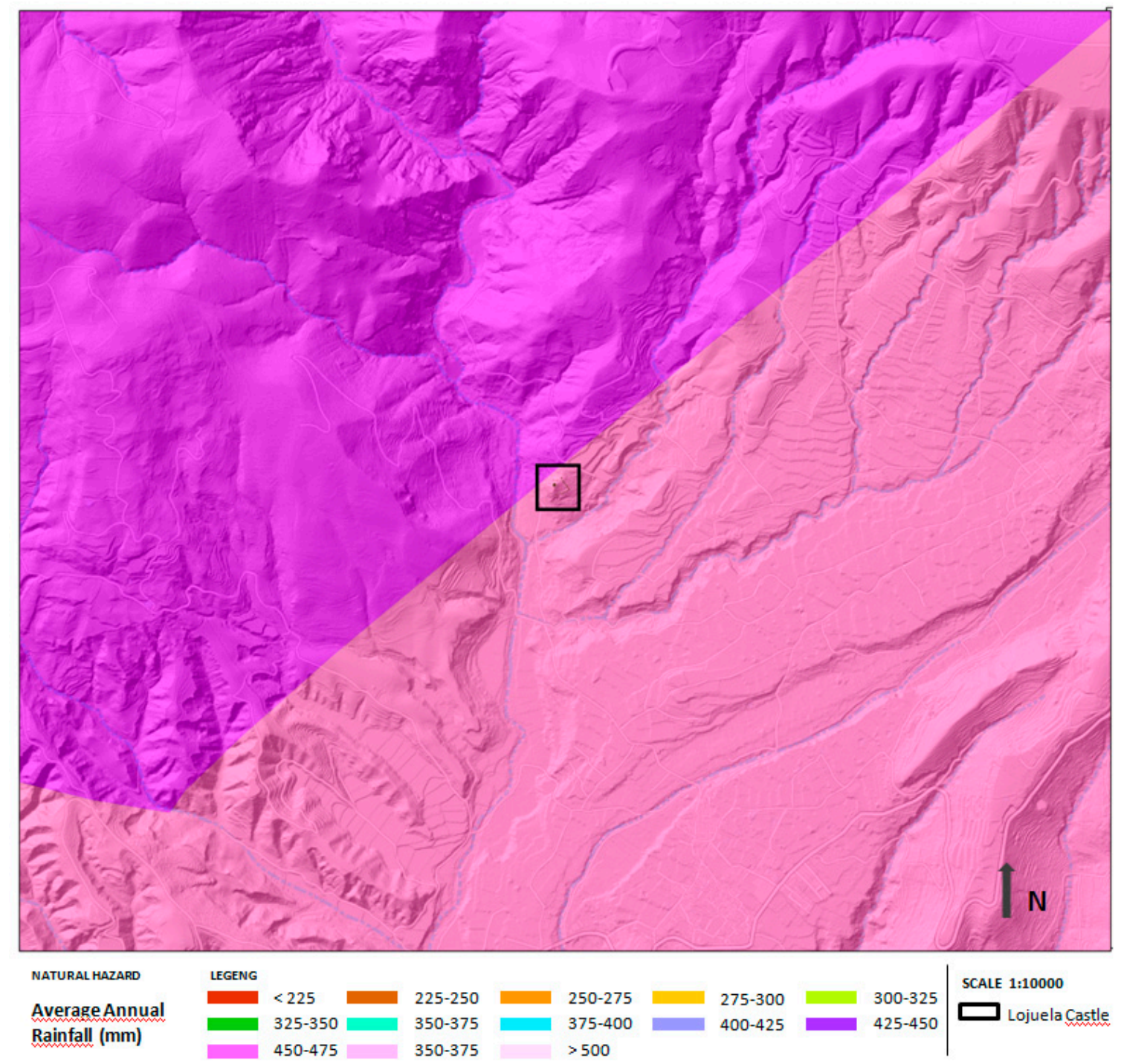

Figure 14. Map of the natural hazards: precipitation (zoom). Source: PREFORTI project.

On the other hand, geological factors present a high degree of risk for the conservation of these structures. While the earthquake and the type of terrain present a medium-low risk in terms of implications for the element, the steep slopes on which the structure rests have had a marked deleterious effect on the structure of the fortification. For example, the appearances of two large cracks in the southwest section of the tower coincide with the areas where the steepest slopes are found and where the fortification is located. Similarly, the complete disappearance of the lower panels of the wall is also associated with this risk factor, although in some cases the origin of the damage was of an anthropic character when drilling the bases of the wall structure.

The anthropic factors place the Lojuela Castle in a situation of medium vulnerability. On one hand, local planning does not delimit its protected area, and since it is located in an urban zone, the risk of urban pressure is medium (Figure 16). The land use risk map, extracted from the SIOSE 2013 for the Autonomous Community of Andalusia, places the castle in a scrubland area close to the irrigated cultivation areas. This location is imprecise; a view of the territory shows that dry farming (almond trees) occupies both the internal and external areas of the fortified enclosure. This fact puts the structure of the asset at greater risk. Furthermore, the fire risk map indicates that these dry crops 
considerably increase the risk of fire in the area surrounding the castle (Figure 17). Combining these high degrees of anthropic risk with the population density map (which presents a minimum risk), it is determined that their level of vulnerability is medium to high.

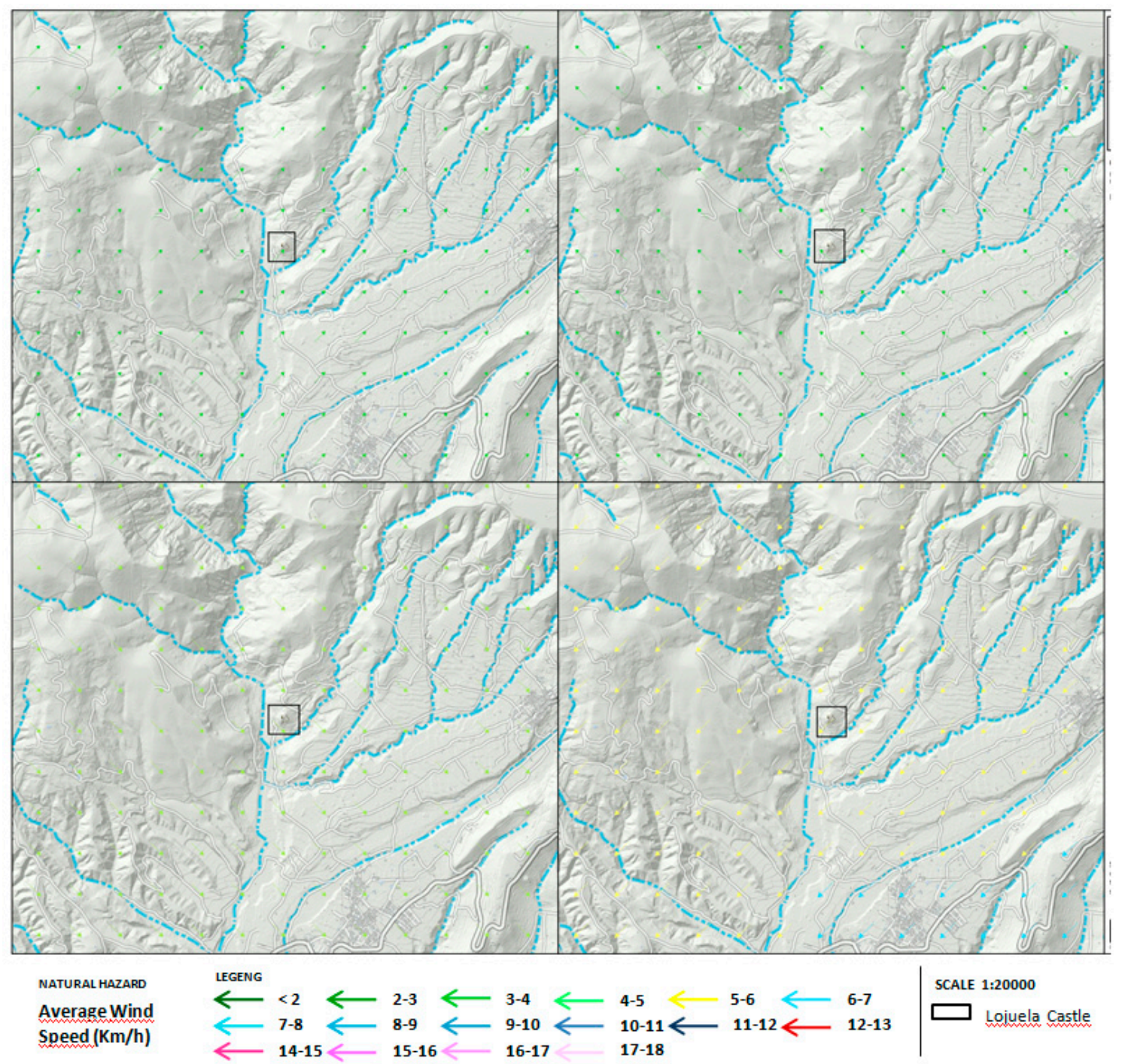

Figure 15. Map of the natural hazards: wind. Source: PREFORTI project.

With a very high incidence, the hazard factor associated with the loss of the original use of the asset stands out. This is a consequence of the absence of minimum conservation and maintenance work and a correct process of adaptation to the environment. This situation, as it has extended over time, has favored the action of vandalism which has led to the significant disappearance of elements of interest. The location of this structure in a natural environment has led to a lack of knowledge about its existence, and therefore about its heritage values for the population. This fact has hindered the development of a cultural identity with this asset that has justified the destruction of its structures when the modification of the environment was required.

From this analysis carried out in micro-zoning, it can be seen that the implementation of sustainable actions both for the asset and with the economic resources available must be carried out in a scaled-up manner: first, by taking into account those linked to curbing the structural imbalance of the asset; then, those that enable the consolidation and protection of the structures by mitigating the effects of the action of water and wind, as well as the adoption of dissuasive measures for animals and educational measures to raise awareness among people; and finally, those that include material restoration actions. 
All of this is done using materials and construction techniques that are compatible with the physical reality and heritage of the castle.

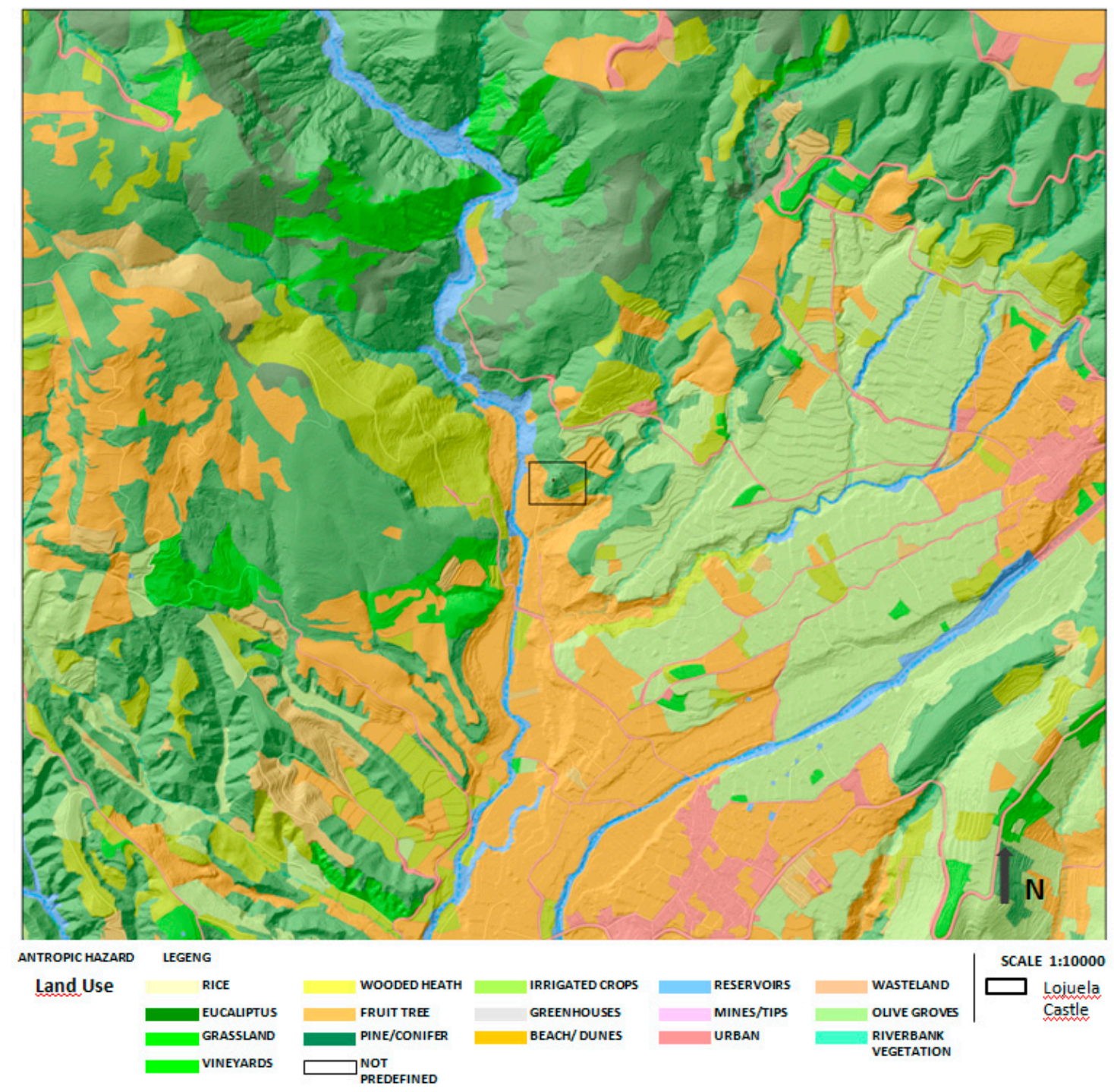

Figure 16. Map of the anthropic hazards: land use. Source: PREFORTI project.

The proposed methodology has been experimentally validated in the walls of the Alcazaba Qadima (Granada), the Alcazaba of Guadix (Granada) and the castle of Velez de Mula (Murcia). All these assets are affected by natural and anthropogenic risks of different types and with a high level of degradation. In these groups, it was possible to carry out the phase of experimentation and validation since the works of material intervention funded by the state, regional and/or local administrations were developed. Moreover, in these cases, the necessary time to evaluate the benefits of the application of the proposed methodology has passed and the link between risk and vulnerability, in relation to the detected pathologies, was confirmed that the preventive measures are working and that the appropriate control strategies were established.

Likewise, it is stated that the method complies with the recommendations of the international heritage doctrine, as well as with the national legislation since it is compatible with the nature of the asset and does not damage its heritage values or those of the environment. The method was presented to bodies such as the Institute of Cultural Heritage of Spain, which belongs to the Ministry of Culture and from the General Directorate of Cultural Heritage of the Andalusian Government. 
Both institutions are competent in the management of Cultural Heritage, and both have shown their interest and support.

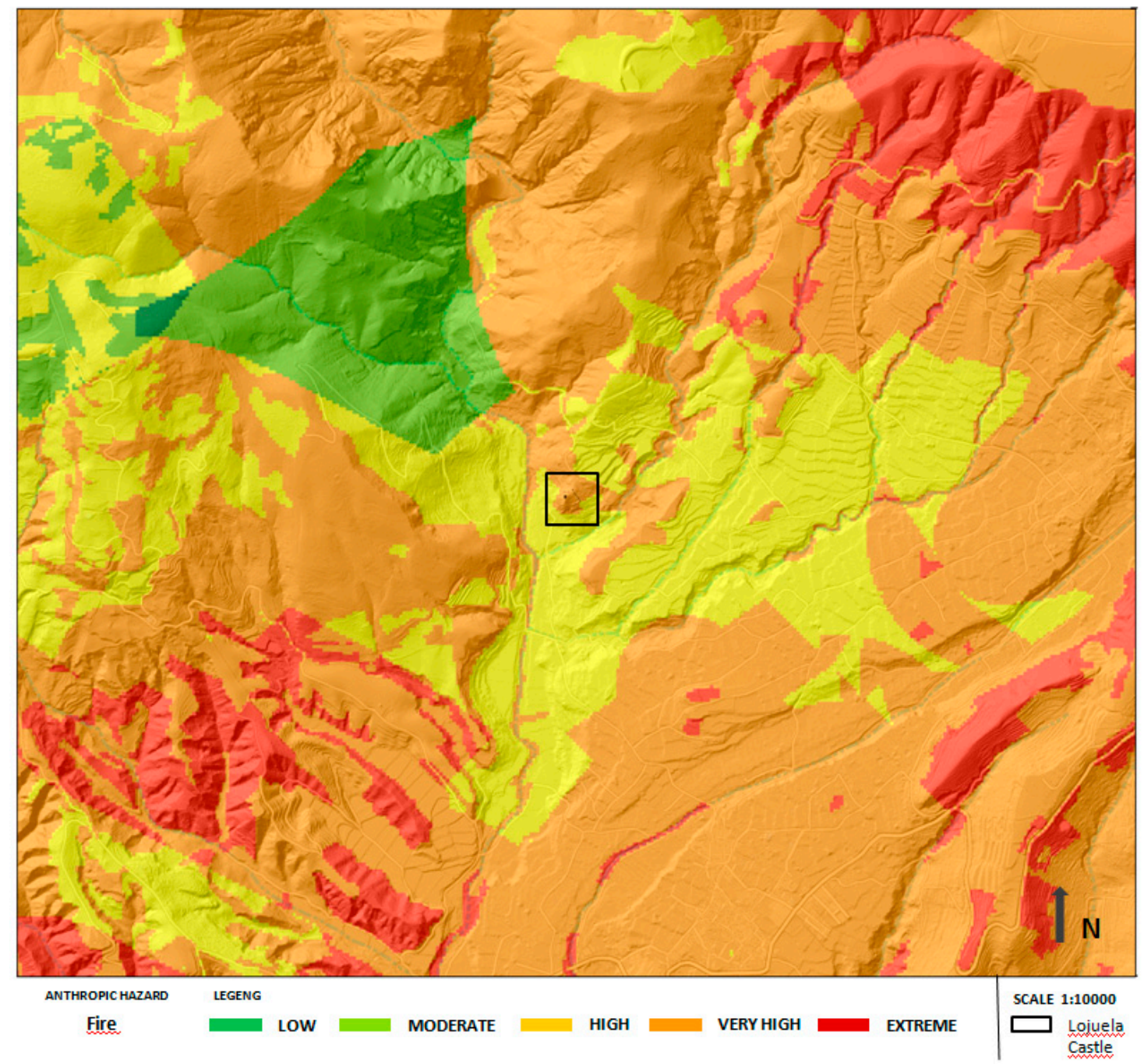

Figure 17. Map of the anthropic hazards: fire. Source: PREFORTI project.

\section{Conclusions}

Having presented and outlined the model proposed for its application to the earthen defensive architecture in the southeast of the Iberian Peninsula, this protocol can be considered useful and effective, and it complies with the parameters established in the management programs. Part of its success is due to have been designed to strengthen the knowledge of the assets and their environment through an interdisciplinary approach. Moreover, it can be extrapolated to other geographical areas with the appropriate and specific modifications for each area. The expansion of global and multidisciplinary knowledge of each of the cultural assets belonging to this specific heritage has an impact on their future economic sustainability (a point highly valued by public and private management). Furthermore, its application through the use of geographical information systems will lead to the rationalization of heritage management in the future since vulnerability studies and risk assessments can be applied to both preventive and sustainable conservation of these structures. Given the high number of medieval earthen fortified assets and the difficulties in controlling and managing them, the use of the GIS facilitates and improves the correct distribution of the limited economic resources available.

In relation to the particular case applied to the Lojuela Castle (Murchas-Granada, Spain) and once the different aspects have been analyzed, it seems that the factors that have greater implications in 
the process of deterioration are, first, those associated with the orography of the terrain and second, the high rate of precipitation. In the last case, when rain is accompanied by moderate wind, it has a direct effect on the facing of the structure.

In order to identify and assess the anthropic risk, the pre-existing maps of the official agencies in charge of its examination were consulted. The lack of updating of these maps and their lack of detail, which is a consequence of the excessively large scale applied to the territory, may lead to inaccuracies in the risks to the property. Consequently, a process of micro-zoning seems necessary to represent in detail the variables that will give rise to the risk maps used.

Any analysis that is limited to a single risk can lead to a distorted view of the real overall consequences for each heritage element. To achieve a rigorous assessment of vulnerability, a combined risk analysis, such as the one presented in this paper seems necessary.

The application of data science and artificial intelligence techniques are envisaged as a line of study to be followed in order to predict the effects that certain hazard factors can have on a protected asset, depending on their incidence and their location in the territory. In this way and supported by the geoprocessing capacities of the GIS, a predictive model could be implemented. It would allow this type of characterization in a wide number of protected assets from a sample already studied.

By estimating degrees of vulnerability, it would be possible to establish geographical priorities for investment in preventive conservation in the face of the high costs involved in restoration a posteriori. As well, it would be possible to favor the sustainable management of heritage protection by public administrations. Finally, we consider the usefulness of predicting and evaluating future scenarios of the effect in the framework of the current climate change.

Author Contributions: Conceptualization, M.L.G.-C.; methodology, M.L.G.-C., I.B.C. and E.M.M.; software, M.L.G.-C.; validation, M.L.G.-C, I.B.C. and E.M.M.; formal analysis, M.L.G.-C.; investigation, M.L.G.-C. and I.B.C.; resources, M.L.G.-C.; data curation, M.L.G.-C. and E.M.M.; writing-original draft preparation, M.L.G.-C. and M.M.C.; writing-review and editing, M.L.G.-C.; visualization, M.L.G.-C. and E.M.M.; supervision, M.L.G.-C.; project administration, M.L.G.-C.; funding acquisition, M.L.G.-C. All authors have read and agreed to the published version of the manuscript.

Funding: This study is part of the project entitled (BIA2015 69938-R) “Sustainable methodology for the Conservation and Maintenance of medieval rammed-earth fortifications in the South-East of the Iberian Peninsula: Diagnosis and prevention of natural and anthropic hazards" financed by the state Research Agency (SRA) and European Regional Development Fund (ERDF).

Acknowledgments: The authors thank the spinoff Tesela Asesoramiento e Innovación en materiales sostenibles S.L., spinoff GIS4tech S.L. and Studio 3c for their collaboration in carrying out the surveys.

Conflicts of Interest: The authors declare no conflict of interest.

\section{References and Note}

1. Xi'an Declaration on the Conservation of the Setting of Heritage Structures, Sites and Areas; ICOMOS: Paris, France, 2005.

2. Camuffo, D. Microclimate for Cultural Heritage; Elsevier: San Diego, CA, USA, 1998.

3. Gizzi, F.T.; Sileo, M.; Biscione, M.; Danese, M.; Alvarez de Buergo, M. The conservation state of the Sassi of Matera site (Southern Italy) and its correlation with the environmental conditions analysed through spatial analysis techniques. J. Cult. Herit. 2016, 17, 61-74. [CrossRef]

4. Canuti, P.; Casagli, N.; Catani, F.; Fanti, R. Hydrogeological hazard and risk in archaeological sites: Some case studies in Italy. J. Cult. Herit. 2020, 1, 117-125. [CrossRef]

5. Sassa, K. Landslide risk assessment at cultural heritage sites. Engineering Geology for Society and Territory. In Landslide Processes; Lollino, G., Giordan, D., Marunteanu, C., Christaras, B., Yoshinori, I., Margottini, C., Eds.; Springer International Publishing: Cham, Switzerland, 2015; Volume 2, pp. 79-103. [CrossRef]

6. Cristi Nicu, I. Natural risk assessment and mitigation of cultural heritage sites in North-eastern Romania (Valea Oii river basin). Area 2019, 51, 142-154. [CrossRef]

7. Ortiz, R.; Ortiz, P.; Martin, J.M.; Vázquez, M.A. A new approach to the assessment of flooding and dampness hazards in cultural heritage, applied to the historic centre of Seville (Spain). Sci. Total Environ. 2016, 551-552, 546-555. [CrossRef] [PubMed] 
8. Gutiérrez-Carrillo, M.L.; Bestué Cardiel, I.; Molina Gaitán, J.C. Manual de Mantenimiento para las Fortificaciones de Tierra; Universidad de Granada: Granada, Spain, 2019.

9. AA.VV. HeritageCARE. Guide Méthodologique de Conservation Préventive; UMinho/DRCN/CCG/USAL/IAPH/ FSMLR/UCA/ULIM: Seville, Spain, 2019.

10. De Güichen, G. La conservation preventive: Un changement profond de mentalité. In Cahiers d'estude; ICOM-CC: Paris, France, 1995.

11. Charter of Krakow. In Principles for Conservation and Restoration of Built Heritage; UNESCO: Paris, France, 2000.

12. Garrido, J.; Gutiérrez-Carrillo, M.L. Andalusian cultural heritage and natural hazards prevention. In Engineering Geology for Society and Territory; Lollino, G., Giordan, D., Marunteanu, C., Christaras, B., Yoshinori, I., Margottini, C., Eds.; Springer: Cham, Switzerland, 2015; Volume 8, pp. 437-440. [CrossRef]

13. De Güichen, G. The causes of the deterioration of heritage. In Presse et Sauvegarde du Patrimoine; VVAA, Ed.; ICCROM: Rome, Italy, 2000; pp. 29-37.

14. Baldi, P. La carta de riesgo del patrimonio cultural. In La Carta de Riesgo. Una Experiencia Italiana Para la Valoración Global de los Factores del Patrimonio Monumental; VVAA, Ed.; Instituto Andaluz de Patrimonio Histórico: Seville, Spain, 1992; pp. 9-14.

15. Macías-Bernal, J.M.; Calama-Rodríguez, J.M.; Chávez-de Diego, M.J. Modelo de predicción de la vida útil de la edificación patrimonial a partir de la lógica difusa. Inf. Constr. 2014, 66, e006. [CrossRef]

16. Ortiz Calderón, P.; Pinto Puerto, F.; Verhagen, P.; Prieto, A. (Eds.) Science and Digital Technology for Cultural Heritage - Interdisciplinary Approach to Diagnosis, Vulnerability, Risk Assessment and Graphic Information Models; CRC Press/Balkema Taylor \& Francis: Leiden, The Netherlands, 2020. Available online: https: //online.vitalsource.com/\#/books/9781000026528/cfi/6!/4/4@0.00:37.8 (accessed on 20 June 2020).

17. Ortiz, P.; Antúnez, V.; Martin, J.M.; Ortiz, R.; Vázquez, M.A.; Galán, E. Approach to environmental risk analysis for the main monuments in a historical city. J. Cult. Herit. 2014, 15, 432-440. [CrossRef]

18. López, A.; Sameño, M. Aplicación del análisis digital de imagen a los estudios de biodeterioro del Patrimonio Histórico. Rev. PH 1998, 5, 86-91.

19. Moropoulou, A.; Koui, M.; Kourteli, C.; Achilleopoulus, N.; Zezza, F. Digital image processing for weathering analysis and planning of conservation interventions on structures and complexes. In Advances in Intelligent Systems. International Series on Microprocessor-Based and Intelligent Systems Engineering; Tzafestas, S.G., Ed.; Springer: Dordrecht, The Netherlands, 1999; pp. 401-414.

20. Ortiz, R.; Ortiz, P.; Vázquez, M.A.; Martín, J.M. Integration of georeferenced informed system and digital image analysis to asses the effect of cars pollution on historical buildings. Constr. Build. Mater. 2017, 139, 320-333. [CrossRef]

21. García Fernández, I.M. Historia de la Conservación preventiva: Parte I. Ge-Conservación 2013, 5, $27-41$. [CrossRef]

22. García Fernández, I.M. Historia de la Conservación preventiva: Parte II. Ge-Conservación 2014, 6, 6-18. [CrossRef]

23. Lillie, M.; Smith, R.; Reed, J.; Inglis, R. Southwest scottish crannogs: Using in situ studies to assess preservation in wetland archaeological contexts. J. Archaeol. Sci. 2008, 35, 1886-1900. [CrossRef]

24. Caragliu, A.; Del Bo, C.; Nijkamp, P. Smart cities in europe. J. Urban Technol. 2011, 18, 65-82. [CrossRef]

25. Allen, K.; Hollinworth, N.; Hwang, F.; Minnion, A.; Kwiatkowska, G.; Lowe, T.; Weldin, N. Interactive sensory objects for improving access to heritage. In Proceedings of the CHI '13 Extended Abstracts on Human Factors in Computing Systems, Paris, France, 27 April 2013; pp. 2899-2902.

26. Lucchi, E. Review of preventive conservation in museum buildings. J. Cult. Herit 2018, 29, 180-193. [CrossRef]

27. Gutiérrez-Carrillo, M.L.; Arizzi, A.; Bestué Cardiel, I.; Sebastián Pardo, E. Study of the state of conservation and the building materials used in defensive constructions in south-eastern Spain: The example of Mula castle in Murcia. Int. J. Archit. Herit. 2019. [CrossRef]

28. Indirli, M.; Razafindrakoto, H.; Romanelli, F.; Puglisi, C.; Lanzoni, L.; Milani, E. Hazard evaluation in Valparaiso: The MAR VASTO Project. Pure Appl. Geophys. 2011, 168, 543-582. [CrossRef]

29. Morelli, S.; Battistini, A.; Catani, F. Rapid assessment of flood susceptibility in urbanizad rivers using digital terrain data: Application to the Arno river case study (Firenze, Northern Italy). Appl. Geogr. 2014, 54, 35-53. [CrossRef] 
30. Unsalan, O.; Kuzucuoglu, A.H. Effects of hazardous pollutants on the walls of Valence Aqueduct (Istanbul) by Raman spectroscopy, SEM-EDX and Geographical Information System. Spectrochim. Acta Part A Mol. Biomol. Spectrosc. 2016, 152, 572-576. [CrossRef]

31. Chávez-Hernández, J.A.; Recarey, C.A.; García-Lorenzo, M.M.; López-Jiménez, O. Utilización de la Inteligencia Artificial en el diagnostico patológico de edificaciones de valor patrimonial. Inf. Constr. 2012, 64, 297-305. [CrossRef]

32. ISO 15686-1:2011. Buildings and Constructed Assets—Service Life Planning; International Organization for Standardization: Gineva, Switzerland, 2011. Available online: https://www.iso.org/obp/ui/es/\#iso:std:iso: 15686:-1:ed-2:v1:en (accessed on 20 June 2020).

33. Claver Gil, J.; García Domínguez, A.; Sebastián Pérez, M.A. AHP adaptation as valuation tool for the selection of the most compatible new uses for assets of the industrial heritage. In Proceedings of the 21th international Congress on Project Management and Engineering, Cádiz, Spain, 12-14 July 2017; pp. 607-615.

34. Cerqua, A.; Gigliarelli, E.; Cessari, L. Application of the Analytic Hierarchy Process (AHP) for energetic rehabilitation of historical buildings. In Proceedings of the 11th International Symposium on Analytic Hierarchy Process, Sorrento, Italy, 11 January 2011; pp. 1-6. Available online: https://www.researchgate.net/publication/215587631_APPLICATION_OF_THE_ANALYTIC_ HIERARCHY_PROCESS_AHP_FOR_ENERGETIC_REHABILITATION_OF_HISTORICAL_BUILDINGS (accessed on 8 July 2020).

35. Camuffo, D.; Van Grieken, R.; Busse, H.-J.; Sturaro, G.; Valentino, A.; Bernardi, A.; Blades, N.; Shooter, D.; Gysels, K.; Deutsch, F.; et al. Environmental monitoring in four European museums. Atmos. Environ. 2001, 35 (Suppl. 1), S127-S140. [CrossRef]

36. Studerman, S.; Tompkins, W.G. (Eds.) Proceeding of the Smithsonian Institution. Summit on the Museum Preservation Environment; Smithsonian Institution Scholarly Press: Washington, DC, USA, 2016.

37. Vantaa Resolution. Towards a European Strategy on Preventive Conservation; ICOM: Paris, France, 2000.

38. UNE-EN 15898-2012 Conservation of Cultural Property-Main General Terms and Definitions; Asociación Española de Normalización: Madrid, Spain, 2012. Available online: https://www.une.org/encuentra-tu-norma/buscatu-norma/norma/?c=N0049099 (accessed on 20 July 2020).

39. National Plan for Preventative Conservation. MECD. 2011. Available online: http://ipce.mcu.es/conservacion/ planesnacionales/preventiva.html (accessed on 20 July 2020).

40. de Güichen, G. Conservación preventiva ¿En qué punto nos encontramos en 2013? Rev. Patrimonio Cult. España 2013, 7, 15-24.

41. Gentile, C.; Saisi, A. Operational modal testing of historic structures at different levels of excitation. Constr. Build. Mater. 2013, 48, 1273-1285. [CrossRef]

42. Merello Giménez, P.; García Diego, F.J.; Zarzo Castelló, M. Diagnosis of abnormal patterns in multivariate microclimate monitoring: A case study of an open-air archaeological site in Pompeii (Italy). Sci. Total Environ. 2014, 488, 14-25. [CrossRef] [PubMed]

43. Merello Giménez, P.; Fernández Navajas, A.; Curiel Esparza, J.; Zarzo Castelló, M.; García Diego, F.J. Characterisation of thermo-hygrometric conditions of an archaeological site affected by unlike boundary weather conditions. Build Environ. 2014, 76, 125-133. [CrossRef]

44. Pachón García, P. Structural Assessment of Historical Buildings by Using the Operational Modal Analysis (OMA) Technique. Ph.D. Thesis, University of Seville, Sevilla, Spain, 2016.

45. Romero, M.; Pachón, P.; Compán, V.; Cámara, M.; Pinto, F. Operational Modal Analysis: A Tool for Assessing Changes on Structural Health State of Historical Constructions after Consolidation and Reinforcement Works-Jura Chapel (Jerez de la Frontera, Spain). Shock Vib. 2018, 16, 1-12. [CrossRef]

46. Arto, I.; Garrido, J.; Gutiérrez-Carrillo, M.L. Seismic vulnerability analysis of medieval rammed earth fortifications in southeastern Spain. Bull. Earthq. Eng. 2020, in press. [CrossRef]

47. Fundamentos de Conservación Preventiva. Instituto del Patrimonio Cultural de España. Available online: http://www.mecd.gob.es/planes-nacionales/dam/jcr:7460d05f-2927-45c4-ba50-1836a35644fd/ CPFundamentos2017.pdf (accessed on 25 February 2019).

48. Herráez, J.A. El concepto de mantenimiento y su encaje en la metodología de trabajo de la conservación preventiva. In Proceedings of the VI Congreso ¿Y después? Control y mantenimiento del patrimonio Cultural, una opción sostenible, Vitoria-Gasteiz, Spain, 20-22 September 2018; Grupo Español del IIC/Ministerio de Cultura y Deporte: Vitoria, Spain, 2018; pp. 72-77. 
49. Minos-Minopoulos, D.; Dominey-Howes, D.; Pavlopoulos, K. Vulnerability assessment of archaeological sites to earthquake hazard: An indicator based method integrating spatial and temporal aspects. Ann. Geophys. 2017, 60, S0445. [CrossRef]

50. Iadanza, C.; Cacace, C.; Del Conte, S.; Spizzichino, D.; Cespa, S.; Trigila, A. Cultural heritage, landslide risk and remote sensing in Italy. In Proceedings of the Landslide Science and Practice: Risk Assessment, Management and Mitigation. 2nd World Landslide Forum, WLF 2011, Rome, Italy, 9-11 October 2011; Volume 6, pp. 491-499. [CrossRef]

51. Villafranca Jiménez, M.M.; Gutiérrez Carrillo, M.L. The Alhambra master plan (2007-2020) as a strategic model of preventive conservation of cultural heritage. Vitruvio Int. J. Archit. Technol. Sustain. 2019, 4, 59-72. [CrossRef]

52. Fregonese, L.; Rosina, E.; Adami, A.; Bottacchi, M.C.; Romoli, E.; Lattanzi, D. Monitoring as strategy for planned conservation: The case of Sant'Andrea in Mantova (Mantua). Appl. Geomat. 2018, 10, 441-451. [CrossRef]

53. Hull, J.; Ewart, I.J. Conservation data parameters for BIM-enabled heritage asset management. Autom. Constr. 2020, 119, 103333. [CrossRef]

54. CEN/TC 346-Conservation Cultural Heritage; European Committee for Standardization: Brussels, Belgium, 2011.

55. Van Balen, K. Preventive conservation of historic buildings. Int. J. Restor. Build.Monum. 2015, 21, 99-104. [CrossRef]

56. Della Torre, S. Critical reflection document on the draft European standard CEN/TC 346 WI 346013 conservation of cultural property- condition survey of immovable heritage (unpublished discussion document). In Proceedings of the Seminar on Condition Reporting Systems for the Built Cultural Heritage, Monumentenwacht, Vlaanderen, 22-24 February 2010.

57. Van Balen, K.; Vandesande, A. Reflections on preventive conservation, maintenance and monitoring. In Preventive Conservation of Built Heritage: Foresight and Needs; Van Balen, K., Vandesande, A., Eds.; ACCO: Leuven, Belgium, 2013; pp. 152-156.

58. Van Balen, K.; Vandesande, A. Community Involvement in Heritage, Reflections on Cultural Heritage Theories and Practices; Garant Publishers: Antwerpen, Belgium, 2015.

59. Van Balen, K.; Vandesande, A. Heritage Counts, Reflections on Cultural Heritage Theories and Practices; Garant Publishers: Antwerpen, Belgium, 2015.

60. National Plan for Defensive Architecture. MECD. 2006. Available online: http://ipce.mcu.es/conservacion/ planesnacionales/defensiva.html (accessed on 20 July 2020).

61. Athens Charter for the Restoration of Historic Monuments, adopted at the First International Congress of Architects and Technicians of Historic Monuments 1931. Available online: https://www.icomos.org/en/167the-athens-charter-for-the-restoration-of-historic-monuments (accessed on 9 September 2020).

62. The Restauro Charter, Rome. 1932. Available online: https://ipce.culturaydeporte.gob.es/dam/jcr:f44dc6ee8eef-4bae-9f08-de93c5be36e8/1932-carta-restauro-roma.pdf (accessed on 9 September 2020).

63. The Venice Charter, International Charter for the Conservation and Restoration of Monuments and Sites; ICOMOS: Paris, France, 1964. Available online: https://www.icomos.org/charters/venice_e.pdf (accessed on 9 September 2020).

64. Convention on the Protection of the World Cultural and Natural Heritage; UNESCO: Paris, France, 1972.

65. The Restauro Charter; Istituto Centrale del Restauro: Rome, Italy, 1972. Available online: https://ipce. culturaydeporte.gob.es/dam/jcr:76a04348-7ea7-48ae-89a4-5b52c7f6f330/1972-carta-restauro-roma.pdf (accessed on 9 September 2020).

66. European Charter of the Architectural Heritage; ICOMOS: París, France, 1975. Available online: https://www.icomos.org/en/resources/charters-and-texts/179-articles-en-francais/ressources/chartersand-standards/170-european-charter-of-the-architectural-heritage (accessed on 9 September 2020).

67. The Declaration of Amsterdam; ICOMOS: Paris, France, 1975. Available online: https://www.icomos.org/en/ and/169-the-declaration-of-amsterdam (accessed on 9 September 2020).

68. Mexico Charter in Defense of Cultural Heritage; UNESCO: Mexico, Mexico, 1976. Available online: https://ipce. culturaydeporte.gob.es/dam/jcr:ac2be1f7-0204-4153-a77a-19d4e580bac9/1976-carta-mexico.pdf (accessed on 9 September 2020). 
69. The Norms of Quito; UNESCO/PNUD: Quito, Ecuador, 1977. Available online: https://ipce.culturaydeporte. gob.es/eu/dam/jcr:da21dfac-4e15-4937-bd6a-d6ead67155be/1967-carta-de-quito.pdf (accessed on 9 September 2020).

70. Convention for the Safeguarding of the Architectural Heritage of Europe; Council of Europe: Strasbourg, France, 1985. Available online: https://rm.coe.int/168007a087 (accessed on 9 September 2020).

71. Charter for the Protection and Management of the Archaeological Heritage; ICOMOS: Paris, France, 1990. Available online: https://www.icomos.org/images/DOCUMENTS/Charters/arch_e.pdf (accessed on 9 September 2020).

72. Decree April 22th 1949 on the Protection of Spanish Castles. Available online: https://www.boe.es/buscar/ doc.php?id=BOE-A-1949-4615 (accessed on 9 September 2020).

73. Spanish Constitution. Official State Bulletin, 29 December 1978.

74. Law of Spanish Historical Heritage, 16/1985, of June 25. Available online: https://www.boe.es/buscar/act. php?id=BOE-A-1985-12534 (accessed on 20 May 2020).

75. Law of Historical Heritage of Andalucia, 14/2007 of November 26. 2007. Available online: https://www. juntadeandalucia.es/boja/2007/248/1 (accessed on 20 May 2020).

76. Schnell Quiertant, P. El inventario de arquitectura defensiva de la AEAC, un ejemplo de ciencia ciudadana en España. Patrimonio Cult. España 2014, 9, 81-94.

77. Carta de Baños de la Encina para la Conservación de la Arquitectura Defensiva en España; Ministerio Cultura: Madrid, Spain, 2006. Available online: https://ipce.culturaydeporte.gob.es/dam/jcr:8a8e781b-d974-4b819bbe-65132490ebff/baniosencina.pdf (accessed on 9 September 2020).

78. Plan for Defensive Architecture in Andalusia; Consejería de Cultura/Junta de Andalucía: Seville, Spain, 2004. Available online: https://www.juntadeandalucia.es/export/drupaljda/PADA_Lineas_generales.PDF (accessed on 9 September 2020).

79. López Guzmán, R. Arquitectura de Al-Andalus (Almería, Granada, Jaén, Málaga); Junta Andalucía/Legado Andalusí/Comares/Fundación Euroarabe: Granada, Spain, 2002.

80. Malpica Cuello, A. Poblamiento y Castillos en Granada; Junta de Andalucía/Legado Andalusí/Lunwerg: Barcelona, Spain, 1996.

81. Martín García, M.; Bleda Portero, J.; Martín Civantos, J.M. Inventario de arquitectura militar de la provincia de Granada (S. VIII al XVIII); Diputación Provincial: Granada, Spain, 1999.

82. Gurriarán Daza, P. Las técnicas constructivas en las fortificaciones andalusíes. In Arqueología medieval: La ciutat; Sabaté i Curull, F., Brufal, J., Eds.; Pagés editors: Lleida, Spain, 2014; pp. 299-328.

83. Gurriarán Daza, P. Las técnicas constructivas en las murallas medievales de Almería. In Defensive Architecture of the Mediterranean; Navarro Palazón, J., García-Pulido, L.J., Eds.; Universidad de Granada; Universitat Politècnica de València; Patronato de la Alhambra y Generalife: Granada, Spain, 2020; Volume X, pp. 61-70. [CrossRef]

84. Ontiveros, E.; Valverde Espinosa, I.; Sebastián Pardo, E. El tapial de las murallas de Granada. Rev. Constr. RE 1997, 26, 58-62.

85. Ontiveros, E.; Valverde Espinosa, I.; Gallego Roca, J.; Sebastián Pardo, E. Estudio de los materiales de construcción de las murallas del Albayzín (Granada). PH Boletín Inst. Andaluz Patrim. Hist. 2008, 66, 32-47.

86. Orihuela, A.; Castillo- Martínez, J.M. Restoration of the Andalusí Wall of the Alcazaba Antigua (Ancient Citadel) of Granada (Cuesta de Alhacaba Area), Rammed Earth Conservation. In Proceedings of the First International Conference on Rammed Earth Conservation. RESTAPIA 2012, Valencia, Spain, 21-23 June 2012; Mileto, C., Vegas, F., Cristini, V., Eds.; CRC Press/Balkema: Boca Raton, FL, USA, 2012; pp. 401-406.

87. Márquez Bueno, S. La tecnología constructiva andalusí: Obra encofrada y revestimientos en la arquitectura militar (ss. XI-XIII). El ejemplo de las torres. Arqueol. Arquit. 2018, 15, e076. [CrossRef]

88. Mileto, C.; Vegas López-Manzanares, F.; Villacampa Crespo, L.; García-Soriano, L. The Influence of Geographical Factors in Traditional Earthen Architecture: The Case of the Iberian Peninsula. Sustainability 2019, 11, 2369. [CrossRef]

89. Graciani, A.; Tabales, M.A. El tapial en el área sevillana. Avance cronotipológico estructural. Arqueol. Arquit. 2008, 5, 135-158. [CrossRef]

90. Graciani, A.; Barrios, A.; Tabales, M.A. Researches in Islamic Tapia Wall Construction in Southern Spain. In Proceedings of the Heritage, Weathering \& Conservation: Proceedings of the International Heritage, Weathering and Conservation Conference (HWC-2006), Madrid, Spain, 21-24 June 2006; Fort, R., Álvarez de Buergo, M., Gómez Heras, M., Vázquez Calvo, C., Eds.; Taylor \& Francis: London, UK, 2008; pp. 109-114. 
91. Ponce-Antón, G.; Arizzi, A.; Zuloaga, M.C.; Cultrone, G.; Ortega, L.A.; Aguirre Mauleón, J. Mineralogical, Textural and Physical Characterisation to Determine Deterioration Susceptibility of Irulegi Castle Lime Mortars (Navarre, Spain). Materials 2019, 12, 584. [CrossRef]

92. Lanzón, M.; De Stefano, V.; Molina Gaitán, J.C.; Bestué Cardiel, I.; Gutiérrez-Carrillo, M.L. Characterisation of earthen walls in the Generalife (Alhambra): Microstructural and physical changes induced by deposition of $\mathrm{Ca}(\mathrm{OH}) 2$ nanoparticles in original and reconstructed samples. Constr. Build. Mater 2020, 232. [CrossRef]

93. López Martínez, F.J. Tapias y tapiales, Loggia. Arquit. Restaur. 1999, 8, 75-80.

94. López Martínez, F.J. Castillo de Monteagudo, Murcia (1995-1997). In La Restauración de la Tapia en la Península Ibérica. Criterios, Técnicas, Resultados y Perspectivas; Mileto, C., Vegas, F., Eds.; Ed Argumentum/TC Cuadernos: Valencia, España, 2014; pp. 246-249.

95. López Martínez, F.J. Restauración del castillo de Alhama. Mínima o máxima intervención. Papeles Partal Rev. Restaur. Monum. 2012, 5, 221-234.

96. Mileto, C.; Vegas, F.; Cristini, V. Rammed Earth Conservation. In Proceedings of the First International Conference on Rammed Earth Conservation, RESTAPIA 2012; CRC Press/Balkema: Boca Raton, FL, USA, 2012.

97. Mileto, C.; Vegas, F. La Restauración de la Tapia en la Península Ibérica. In Criterios, Técnicas, Resultados y Perspectivas; Argumentum/TC Cuadernos: Valencia, España, 2014.

98. Mileto, C.; Vegas López-Manzanares, F.; García-Soriano, L. La restauración de la tapia monumental: Pasado, presente y futuro. Inf. Constr. 2017, 69, e231. [CrossRef]

99. Mileto, C.; Vegas, F.; García-Soriano, L.; Cristini, V. Vernacular and earthen Architecture. Conservation and Sustainability; Balkema-Taylor \& Francis: Amsterdam, The Netherlands, 2018.

100. Mileto, C.; Vegas López-Manzanares, F. The COREMANS Project. Intervention criteria for Earthen Architecture; Secretaría General Técnica, Subdirección General de Documentación y Publicaciones, Ministerio de Educación, Cultura y Deporte: Madrid, Spain, 2017. [CrossRef]

101. Garrido, J.; Gutiérrez-Carrillo, M.L.; Molero Melgarejo, E. Risk charter for medieval defensive earthen architecture in southern Spain. World Multidisciplinary Earth Sciences Symposium (WMESS 2019). In IOP Conference Series: Earth and Environmental Science; IOP Publishing: Bristol, UK, 2019; Volume 362, p. 012078. [CrossRef]

102. Agnoletti, M.; Errico, A.; Santoro, A.; Dani, A.; Preti, F. Terraced Landscapes and Hydrogeological Risk. Effects of Land Abandonment in Cinque Terre (Italy) during Severe Rainfall Events. Sustainability 2019, 11, 235. [CrossRef]

103. Niculiţă, M.; Mărgărint, M.C. Landslides and Fortified Settlements as Valuable Cultural Geomorphosites and Geoheritage Sites in the Moldavian Plateau, North-Eastern Romania. Geoheritage 2018, 10, 613-634. [CrossRef]

104. García Codrón, J.C. Las ciudades españolas y el riesgo de inundación: Permanencia y cambio de un problema crónico. Boletín A.G.E. 2004, 37, 85-99.

105. Azañón, J.M.; Azor, A.; Booth-Rea, G.; Torcal, F. Small-scale faulting, topographic steps and seismic ruptures in the Alhambra (Granada, Southeast Spain). J. Quat. Sci 2004, 19, 219-227. [CrossRef]

106. Justo, J.L.; Azañón, J.M.; Azor, A.; Saura, J.; Durand, P.; Villalobos, M.; Morales, A.; Justo, E. Neotectonics and slope stabilization at the Alhambra, Granada, Spain. Eng. Geol. 2008, 100, 101-119. [CrossRef]

107. Brazille Naulet, V.C.; Orihuela Uzal, A.; García-Pulido, L.J. La Torre de Comares en peligro de ruina. Afecciones de la estructura más significativa de la Alhambra en los siglos XVI y XVI. In Defensive Architecture of the Mediterranean; Navarro Palazón, J., García-Pulido, L.J., Eds.; Universidad de Granada; Universitat Politècnica de València, Patronato de la Alhambra y Generalife: Granada, Spain, 2020; Volume X, pp. 21-28. [CrossRef]

108. Cuéllar Mirasol, V. Trabajos realizados y coordinados por el centro de estudios y experimentación de obras Públicas. Cuadernos Alhambra 1998, 33-34, 9-16.

109. Gutiérrez-Carrillo, M.L.; Bestué Cardiel, I.; Molina Gaitán, J.C.; Martínez López, J.A. PREFORTI Project: Preventive Conservation in Fortified Heritage in Rammed Earth. In Vernacular and Earthen Architecture. Conservation and Sustainability; Mileto, C., Vegas López-Manzanares, F., García Soriano, L., Cristini, V., Eds.; CRC Press/Balkema, Taylor \& Francis: London, UK, 2018; pp. 447-452. 
110. Quattrone, G. Risk analysis and vulnerability assessment of archeological areas for the preventive conservation. In Digital Heritage. Progress in Cultural Heritage: Documentation, Preservation, and Protection, Proceeding 6th International Conference EuroMed 2016, Nicosia, Cyprus, 31 October-5 November 2016; Ioannides, M., Fink, E., Moropoulou, A., Hagedorn-Saupe, M., Fresa, A., Liestøl, G., Rajcic, V., Grussenmeyer, P., Eds.; Springer: Cham, Switzerland, 2016; Volume 1, pp. 157-168.

111. Gutiérrez-Carrillo, M.L.; Bestué Cardiel, I. Catalogue for Preventive preservation: Knowledge and analysis of risks in the earthen defensive architecture. In Proceedings of the 4th International Conference on Preservation, Maintenance and Rehabilitation of Historic Buildings and Structures, Guimaraes, Portugal, 17-19 July 2019; Amoêda, R., Lira, S., Pinhero, C., Eds.; Green Lines Institute for Sustainable Development: Barcelos, Portugal, 2019; pp. 3-12.

112. Parenti, R. Historia, importancia y aplicaciones del método de lectura de paramentos. Inf. Constr. 1995, 46, 19-29. [CrossRef]

113. Benavides López, J.A.; Martín Civantos, J.M.; Rouco Collazo, J. Levantamiento arquitectónico y análisis arqueológico del castillo de Pínar como punto de partida para su conservación. Virtual Archeol. Rev. 2020, 11, 95-115. [CrossRef]

114. Rouco Collazo, J.; Martín Civantos, J.M.; Benavides López, J.A. Building Archaeology of the Alcazaba of Guadix (Granada, Spain): An Example of Implanting Power in the Urban Centres of Al-Andalus. Int. J. Archit. Herit. 2020. [CrossRef]

115. National Plan for Disaster Risk Management of Cultural Heritage. MECD. 2015. Available online: http://www.Mecd.Gob.Es/Planes-Nacionales/Planes/Emergencias.Html (accessed on 20 July 2020).

116. Molero, E.; Gutiérrez-Carrillo, M.L.; Garrido, J. Implementing a GIS for cataloguing of medieval defensive earth architecture. In Vernacular and Earthen Architecture. Conservation and Sustainability; Mileto, C., Vegas López-Manzanares, F., García Soriano, L., Cristini, V., Eds.; CRC Press/Balkema, Taylor \& Francis: London, UK, 2018; Volume 1, pp. 471-476.

117. Asprone, D.; Jalayer, F.; Prota, A.; Manfredi, G. Proposal of a probabilistic model for multi-hazard risk assessment of structures in seismic zones subjected to blast for the limit state of collapse. Struct. Saf. 2010, 32, 25-34. [CrossRef]

118. Ortiz, R.; Macías-Bernal, J.M.; Ortiz, P. Vulnerability and buildings service life applied to preventive conservation in cultural heritage. Int. J. Disaster Resil. Built Environ. 2018, 9, 31-47. [CrossRef]

119. Xue, K.; Yifei Li, Y.; Meng, X. An evaluation model to assess the communication effects of intangible cultural heritage. J. Cult. Herit. 2019, 40, 124-132. [CrossRef]

120. Molero Melgarejo, E.; Casado, D.; Gutiérrez-Carrillo, M.L. GIS methodology and Spatial Data infraestructure for risk analysis in Medieval Defensive Earth Architecture: Territorial characterization through spatial analysis, Delphi method and analytic hierarchy process. In Science and Digital Technology for Cultural Heritage - Interdisciplinary Approach to Diagnosis, Vulnerability, Risk Assessment and Graphic Information Models; Ortiz Calderón, P., Pinto Puerto, F., Verhagen, P., Prieto, A., Eds.; CRC Press/ Balkema Taylor \& Francis: Leiden, The Netherlands, 2020; Volume 1, pp. 155-159. [CrossRef]

121. Reguant-Álvarez, M.; Torrado-Fonseca, M. El método Delphi. REIRE. Rev. D'innovació Recerca Educació 2016, 9, 87-102. [CrossRef]

122. Landeta, J. El método Delphi. Una Técnica de Previsión Para la Incertidumbre; Ariel: Barcelona, España, 1999.

123. Gutiérrez-Carrillo, M.L.; Bestué Cardiel, I.; Molina Gaitán, J.C.; Marcos Cobaleda, M. Methodology for the analysis of risk as applied to medieval earthen defensive structures. In The Case of the Lojuela Castle (Granada-Spain), Proceedings of the Patrimonio in divenire: Conoscere, Valorizzare, Abitare, ReUSO 2019, Matera, Italy, 23-26 October 2019; Conte, A., Guida, A., Eds.; Gangemi Editore International Publishing: Rome, Italy, 2019; pp. 1695-1706.

124. Tesela, S.L. Technical-Scientific Report on the Analysis of Building Materials from Earthen Fortifications in the Province of Granada (Unpublished); Tesela S.L.: Granada, Spain, 2017.

125. Official Bulletin of the Granada Province 5th of June 2000.

126. Consejería de Cultura. El Catastro del Marqués de la Ensenada en el Antiguo Reino de Granada; Consejería de Cultura: Sevilla, Spain, 2004. 
127. Reyes Castañeda, J.L. Técnicas de construcción de las fortificaciones en el reino de Granada: El Valle de Lecrín. In Proceedings of the Actas del III Simposio Internacional de Mudejarismo, Teruel, España, 20-22 September 1984; Instituto de Estudios Turolenses/Diputación de Teruel: Teruel, España, 1986; Volume 1, pp. 373-388.

128. Coppolillo, P.; Gomez, H.; Maisels, F.; Wallace, R. Selection criteria for suites of landscape species as a base for site-based conservation. Conser. Biol. 2004, 115, 419-430. [CrossRef]

129. Halpern, B.S.; Selkoe, K.A.; Micheli, F.; Kappel, C.V. Evaluating and ranking the vulnerability of global marine ecosystems to anthropogenic threats. Conser. Biol. 2007, 21, 1301-1315. [CrossRef]

(C) 2020 by the authors. Licensee MDPI, Basel, Switzerland. This article is an open access article distributed under the terms and conditions of the Creative Commons Attribution (CC BY) license (http://creativecommons.org/licenses/by/4.0/). 